\title{
Removal of Pharmaceutical Micropollutants with Integrated Biochar and Marine Microalgae
}

\author{
Amin Mojiri ${ }^{1, *,+}$, , Maedeh Baharlooeian ${ }^{2,+}$, Reza Andasht Kazeroon ${ }^{3}$, Hossein Farraji ${ }^{4}$ and Ziyang Lou ${ }^{5}$ \\ 1 Department of Civil and Environmental Engineering, Graduate School of Advance Science and Engineering, \\ Hiroshima University, Higashihiroshima 739-8527, Japan \\ 2 Department of Marine Biology, Faculty of Marine Science and Oceanography, Khorramshahr University of \\ Marine Science and Technology, Khorramshahr 669, Iran; bbenicka@yahoo.com \\ 3 Faculty of Civil Engineering, Xi'an University of Architecture and Technology, Xi'an 710055, China; \\ reza.andasht@gmail.com \\ 4 School of Physical and Chemical Sciences, University of Canterbury, Christchurch 8140, New Zealand; \\ faraji6211@gmail.com \\ 5 School of Environmental Science and Engineering, Shanghai Jiao Tong University, Shanghai 200240, China; \\ louworld12@sjtu.edu.cn \\ * Correspondence: amin.mojiri@gmail.com \\ + These authors contributed equally to this work.
}

Citation: Mojiri, A.; Baharlooeian, M.; Kazeroon, R.A.; Farraji, H.; Lou, Z. Removal of Pharmaceutical Micropollutants with Integrated Biochar and Marine Microalgae. Microorganisms 2021, 9, 4 . https://dx.doi.org/10.3390/ microorganisms 9010004

Received: 3 December 2020

Accepted: 17 December 2020

Published: 22 December 2020

Publisher's Note: MDPI stays neutral with regard to jurisdictional claims in published maps and institutional affiliations.

Copyright: () 2020 by the authors. Licensee MDPI, Basel, Switzerland. This article is an open access article distributed under the terms and conditions of the Creative Commons Attribution (CC BY) license (https://creativecommons.org/ licenses/by/4.0/).

\begin{abstract}
Using microalgae to remove pharmaceuticals and personal care products (PPCPs) micropollutants (MPs) have attracted considerable interest. However, high concentrations of persistent PPCPs can reduce the performance of microalgae in remediating PPCPs. Three persistent PPCPs, namely, carbamazepine (CBZ), sulfamethazine (SMT) and tramadol (TRA), were treated with a combination of Chaetoceros muelleri and biochar in a photobioreactor during this study. Two reactors were run. The first reactor comprised Chaetoceros muelleri, as the control, and the second reactor comprised Chaetoceros muelleri and biochar. The second reactor showed a better performance in removing PPCPs. Through the response surface methodology, $68.9 \%\left(0.330 \mathrm{mg} \mathrm{L}^{-1}\right)$ of $\mathrm{CBZ}, 64.8 \%\left(0.311 \mathrm{mg} \mathrm{L}^{-1}\right)$ of SMT and $69.3 \%\left(0.332 \mathrm{mg} \mathrm{L}^{-1}\right)$ of TRA were removed at the initial concentrations of MPs $(0.48 \mathrm{mg}$ $\mathrm{L}^{-1}$ ) and contact time of 8.1 days. An artificial neural network was used in optimising elimination efficiency for each MP. The rational mean squared errors and high $R^{2}$ values showed that the removal of PPCPs was optimised. Moreover, the effects of PPCPs concentration $\left(0-100 \mathrm{mg} \mathrm{L}^{-1}\right)$ on Chaetoceros muelleri were studied. Low PPCP concentrations $\left(<40 \mathrm{mg} \mathrm{L}^{-1}\right)$ increased the amounts of chlorophyll and proteins in the microalgae. However, cell viability, chlorophyll and protein contents dramatically decreased with increasing PPCPs concentrations $\left(>40 \mathrm{mg} \mathrm{L}^{-1}\right)$.
\end{abstract}

Keywords: biochar; carbamazepine; emerging micropollutant; microalgae; sulfamethazine; tramadol

\section{Introduction}

Industrial and agricultural activities are the main sources of water pollution around the world [1]. In the scientific literature and CAS registry, more than 150 million inorganic and organic pollutants have been recorded [2]. The continuous input of microcontaminants to water bodies is a growing environmental problem given that many of these microcontaminants are non-biodegradable, persistent and bioaccumulative [3]. Among the important categories of these pollutants are emerging micropollutants, which can be detected in the environment at trace concentrations. These contaminants comprise personal care products, pharmaceuticals, pesticides, metallic trace elements and industrial chemicals [4]. Vakili et al. [5] demonstrated that conventional treatment techniques used by municipal wastewater treatment plants have failed to eliminate emerging micropollutants completely.

Pharmaceuticals and personal care products (PPCPs) constitute an important class of emerging micropollutants. Tons of PPCPs are annually produced, consumed and finally 
discharged into the environment [6]. Therefore, some of the most persistent PPCPs, namely, carbamazepine (CBZ), sulfamethazine (SMT) and tramadol (TRA), were investigated in the present study. Yentür and Dükkanc1 [7] stated that CBZ, as an antiepileptic drug, has been usually used to treat epilepsy and bipolar disorder. Approximately $10 \%$ of CBZ may be eliminated from wastewater through conventional treatment [7]. SMT is a common sulfonamide antibiotic and used in animal husbandry and aquatic farming. Approximately $50 \%$ of consumed SMT remains unmetabolised in parent animals and may be excreted to water bodies [8]. Another investigated PPCP in this study is TRA, which is a painkiller and opioid analgesic [9]. It is not completely eliminated by wastewater treatment plants and usually discovered in effluents after treatment and in surface waters [10]. Consequently, the removal of these micropollutants has become a worldwide concern [3]. Thus, several physicochemical and biological methods for removing PPCPs from water bodies have been reported [11]. One of several techniques for treating microcontaminants is bioremediation, a low-cost and environmentally friendly method. It is a procedure that involves the use of microorganisms, such as bacteria, fungi and algae, in degrading and transforming contaminants into less toxic forms [12]. Microalgae have attracted the attention of researchers in the field of PPCP removal through bioremediation [13]; microalga systems have a dual capability to treat wastewater efficiently and produce biomass for the production of biofuel, biofertiliser or other useful products [14].

Robledo-Padilla et al. [15] expressed that several marine or freshwater microalgae can be used for the removal of organic pollutants. Jiménez-Bambague et al. [16] removed $30-70 \%$ of PPCPs from domestic wastewater under tropical conditions by using green microalgae. Meanwhile, the capability of the marine diatom Chaetoceros muelleri to remove PPCPs has not been thoroughly explored in previous studies. Minggat et al. [17] stated that Chaetoceros muelleri is frequently used in aquacultural feed and is well known for its fast growth and easy maintenance. Wang et al. [18] stated that Chaetoceros muelleri is one of the suitable microalgae for large-scale biomass and lipid production. Karthikeyan et al. [19] used Chaetoceros sp. in macronutrient removal from wastewater. Mulla et al. [20] showed that hydraulic retention time, high concentration of PPCPs and seasonality could affect the efficiency of systems in removing several microcontaminants. To reduce the effects of these factors on microalgal activities, we added biochar to our system.

Biochar is a carbonaceous material produced from biomass feedstock through thermochemical decomposition in the presence of little oxygen or in the absence of oxygen [21]. Biochar is a promising adsorbent for low-cost wastewater treatment. It can be integrated into different treatment techniques to enhance the performance of a system [22]. Gorovtsov et al. [23] demonstrated that biochar could enhance the organism growth and activities by supplying nutrients and immobilising organisms on its surface.

Organic microcontaminants in aquatic environments can cause toxic effects on microorganisms, such as microalgae [24]. Therefore, most researchers [25-27] have attempted to evaluate the individual effects of organic microcontaminants on microalgae. Meanwhile, the combined effects of some emerging micropollutants on marine diatoms have not been extensively explored.

Therefore, the objectives of the current study were as follows: Firstly, an integrated system comprising biochar and Chaetoceros muelleri (marine diatom) was designed as a photobioreactor to remove PPCPs from synthetic wastewater, and the performance of the system was optimised using the response surface methodology (RSM) and an artificial neural network (ANN). The currently reported system has not been described in previous researches. Secondly, the effect of PPCPs on Chaetoceros muelleri was investigated.

\section{Materials and Methods}

CBZ, SMT and TRA of $\geq 98 \%$ purity (Table 1 ), distilled water and methanol were supplied by Sigma-Aldrich Co (Petaling Jaya, Malaysia). Stock solutions $\left(1 \mathrm{~g} \mathrm{~L}^{-1}\right)$ were prepared by individually dissolving the compounds in distilled water [28]. Chaetoceros muelleri was obtained from the photobioreactor in our laboratory. 
Table 1. Characteristics of the pharmaceuticals.

\begin{tabular}{ccccc}
\hline Pharmaceuticals & Structure & CAS Number & Molecular Weight (mg) & References \\
\hline Carbamazepine (CBZ) & $\mathrm{C}_{15} \mathrm{H}_{12} \mathrm{~N}_{2} \mathrm{O}$ & $298-46-4$ & 235.3 & {$[29]$} \\
Sulfamethoxazole (SMT) & $\mathrm{C}_{10} \mathrm{H}_{11} \mathrm{~N}_{3} \mathrm{O}_{3} \mathrm{~S}$ & $723-46-6$ & 253.3 & {$[29]$} \\
Tramadol (TRA) & $\mathrm{C}_{16} \mathrm{H}_{25} \mathrm{NO}_{2}$ & $27203-92-5$ & 263.37 & {$[9]$} \\
\hline
\end{tabular}

\subsection{Experimental Setup}

Chaetoceros muelleri was cultivated (Supplementary Materials, Figure S1) according to the method described by González-González et al. [30]. Briefly, the algae were cultivated in a F/2 medium in artificial seawater under constant light of around $66 \mu \mathrm{mol}$ photons $\mathrm{m}^{-2} \mathrm{~s}^{-1}$ [31] at $25^{\circ} \mathrm{C}$. Then, the microalgae were transferred to an eight $\mathrm{L}$ bubble column photobioreactor under white fluorescent light illumination $\left(66 \mu \mathrm{mol}\right.$ photons $\left.\mathrm{m}^{-2} \mathrm{~s}^{-1}\right)$ at room temperature. Two photobioreactors (Figure 1) were used. One of the photobioreactors contained Chaetoceros muelleri (first reactor), and another contained Chaetoceros muelleri and $20 \mathrm{~g} \mathrm{~L}^{-1}$ of biochar (biochar dose was selected according to preliminary experiments and hanged in the reactor; second reactor). On the basis of preliminary experiments, aeration rate was set at $0.4 \mathrm{~L} / \mathrm{min}$ [32] in both reactors. Synthetic aqueous solution was produced by dissolving PPCPs and artificial seawater. The concentrations of PPCPs ranged from $0.2 \mathrm{mg} \mathrm{L}^{-1}$ to $1 \mathrm{mg} \mathrm{L}^{-1}$. According to preliminary experiments, hydraulic retention time was set at 2.8 days. This setup is in line with the findings of Jiménez-Bambague et al. [16].

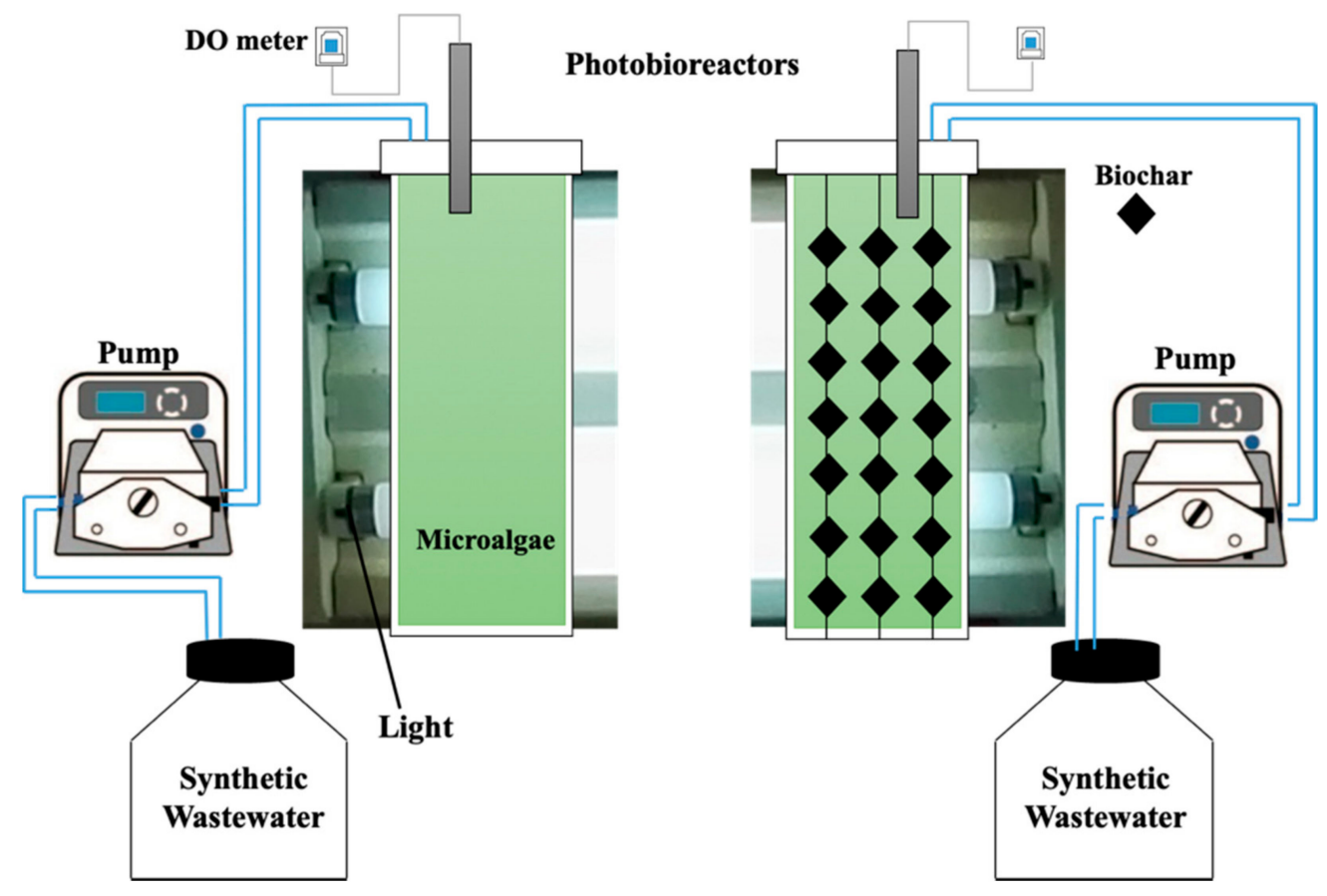

Figure 1. Schematics of the photobioreactors.

\subsection{Organic Micropollutant Measurements and Biochar Characteristic Monitoring}

A high-pressure liquid chromatograph (LC-20AT, Shimadzu International Trading Co., Ltd., Tokyo, Japan) with a UV detector was used in monitoring the concentrations of the organic micropollutants. The mobile phases were acetonitrile and $\mathrm{NaH}_{2} \mathrm{PO}_{4}$ in a ratio of $40 / 60$. The limit of detection was determined using the expression $3 \sigma / \mathrm{s}$, where $\sigma$ is the standard deviation of the peak and $s$ defines the slope of the corresponding calibration curve [28]. Biochar (derived from agricultural wastes) was used in this study. BET surface analysis was conducted using autosorb (Quantachrome AS1WinTM-automated gas-sorption apparatus, Boynton Beach, FL, USA). 


\subsection{Optimisation Analysis}

PPCP removal efficiency was assessed using the following equation (Equation (1)).

$$
\operatorname{Removal}(\%)=\frac{\text { Initial concentration }\left(m g L^{-1}\right)-\text { Final concentration }\left(m g L^{-1}\right)}{\text { Initial concentration }\left(m g L^{-1}\right)} \times 100
$$

RSM and central composite design were used in optimising the reactors' efficiency in eliminating PPCPs, reaction (contact) time (0.5-9 days) and the initial concentrations of PPCPs (0.2-1 mg L $\left.{ }^{-1}\right)$. In this step, the Design Expert Software (Version 10) was used. Each factor had three levels, and thus a quadratic model was considered a suitable model (Equation (2)) [33].

$$
Y=\beta_{0}+\sum_{j=1}^{k} \beta_{j} X_{j} \sum_{j=1}^{k} \beta_{j j} X_{j}^{2} \sum_{j=1} \sum_{j>1}^{k} \beta_{j j} X_{j} X_{j}+e
$$

where, $Y$ is response, $\beta_{0}$, and $\beta_{i}$ are fixed coefficients, $\beta_{j}$ and $\beta_{i j}$ interface coefficients, $X_{i}$ and $X_{j}$ are variables and $e$ represents error.

Furthermore, ANN was used in optimising PPCP removal in each photobioreactor. Optimisation was implemented in MATLAB R2015a. The topology of the ANN, containing the input, hidden and output layers, is shown in Figure S2. In this study, the initial concentrations of PPCPs and reaction time were two neurons of input. The five neurons in the hidden layer and one neuron in the output layer were considered in the ANN. $R^{2}$ and mean squared errors (MSE; Equations (3) and (4)) were evaluated for the monitoring of model performance [34]. Approximately, $60 \%, 20 \%$ and $20 \%$ of data were considered in training, validation and testing, respectively.

$$
\begin{aligned}
& R^{2}=1-\frac{\sum_{i=1}^{N}\left(||_{p r d, i}-e_{\text {exp }, i} \mid\right)}{\sum_{i=1}^{N}\left(||_{p r d, i}-{ }_{m} \mid\right)} \\
& M S E=\frac{1}{N} \sum_{i=1}^{N}\left(\left|{ }_{p r d, i}-{ }_{\text {exp }, i}\right|\right)^{2}
\end{aligned}
$$

where by $y_{p r d, i}$ is the anticipated value of the ANN model, $y_{\text {exp }, i}$ denotes the experimental value and $N$ and $y_{m}$ denotes the number of data and the average of the experimental values, respectively.

\subsection{Effects of Pharmaceuticals and Personal Care Products on Microalgae}

To monitor the effects of pharmaceutical micropollutants on microalgae, we carried out the batch experiments according to the methods described by Tsiaka et al. [27]. Briefly, after the cultivation of the microalgae in the $\mathrm{F} / 2$ medium, a suitable amount of biomass $\left(1 \times 10^{4}\right.$ cells $\left.\mathrm{mL}^{-1}\right)$ was transferred to a conical sterilised flask series and then exposed to various concentrations of TRA, SMT and CBZ $\left(0-100 \mathrm{mg} \mathrm{L}^{-1}\right)$ for 24-96 h under constant light of $66 \mu \mathrm{mol}$ photons $\mathrm{m}^{-2} \mathrm{~s}^{-1}$. Total protein was measured at the wavelength of $595 \mathrm{~nm}$ with a UV-Vis spectrophotometer according to the methods described by Chia et al. [35] Carotenoids were analysed with a spectrophotometer (UV-1601PC, Shimadzu, Tokyo, Japan) at 470, 630 and $664 \mathrm{~nm}$ according to the methods described by Wang et al. [18]. Homogenous suspensions of the samples at $100 \mathrm{~mL}$ each were centrifuged at $6000 \times g$ for $12 \mathrm{~min}$, and the obtained cell pellets were resuspended in $20 \mathrm{~mL}$ of acetone. The solvent biomass mixture was incubated at $45 \pm 50^{\circ} \mathrm{C}$ in a water bath for $2 \mathrm{~h}$ with shaking. The following equations (Equations (5)-(7)) [18] were used in calculating carotenoid content.

$$
\begin{aligned}
& \text { Chlorophyll } a\left(\mu \mathrm{g} \mathrm{mL}^{-1}\right)=\left(11.47 \mathrm{~A}_{664}\right)-\left(0.4 \mathrm{~A}_{630}\right) \\
& \begin{array}{c}
\text { Chlorophyll } c\left(\mu \mathrm{g} \mathrm{mL}^{-1}\right)=\left(24.36 \mathrm{~A}_{630}\right)-\left(3.73 \mathrm{~A}_{664}\right) \\
\qquad \mathrm{C}_{\mathrm{X}+\mathrm{c}}=\left(1000 \mathrm{~A}_{470}-2.27 \mathrm{C}_{\mathrm{a}}-81.4 \mathrm{C}_{\mathrm{b}}\right)
\end{array}
\end{aligned}
$$


where, absorbance levels at 470, 664 and $630 \mathrm{~nm}$ are indicated by $\mathrm{A}_{470}, \mathrm{~A}_{664}$ and $\mathrm{A}_{630}$, respectively.

Optical cell density of $680 \mathrm{~nm}\left(\mathrm{OD}_{680}\right)$ was used in monitoring cell growth [36], and then cytotoxicity assay was calculated using Equation (8) [37].

$$
\text { Cell viability }(\%)=\frac{A_{E}-A_{B}}{A_{C}-A_{B}} \times 100
$$

where, the mean of absorbance levels of the blank and control cells are indicated by $A_{B}$ and $A_{C}$, respectively, and $A_{E}$ shows the mean of absorbance of the cells exposed to the PPCPs.

\subsection{Adsorption Isotherm for Micropollutant Removal by Biochar}

As batch experiments, adsorption isotherm study was performed in beakers containing PPCPs $\left(0.5 \mathrm{mg} \mathrm{L}^{-1}\right)$ and different doses of biochar $\left(0-25 \mathrm{~g} \mathrm{~L}^{-1}\right)$. The beakers were shaken at $200 \mathrm{rpm}$ for $24 \mathrm{~h}$. Then, Equation (9) was used in evaluating adsorption capacity ( $\mathrm{q}_{\mathrm{e}}$, $\left.\mathrm{mg} \mathrm{g}^{-1}\right)$.

$$
q_{e}=\frac{\left(C_{O}-C_{e q}\right) V}{M_{S}}
$$

where, $V$ denotes volume (L), $M_{\mathcal{S}}$ denotes adsorbent mass $(\mathrm{g})$ and $C_{0}$ and $C_{e}$ are the initial and final concentrations of PPCPs, respectively.

\section{Results and Discussion}

This study had two parts. In the first part, CBZ, SMT and TRA were removed with two photobioreactors (one containing Chaetoceros muelleri (a marine diatom, first reactor) and another containing Chaetoceros muelleri + biochar (second reactor)). Details about PPCP removal with both reactors are shown in Tables 2 and 3. The performance of each reactor was optimised with the RSM and ANN. Table 4 and Figures 2-5 display the details of the optimisation process. In the second part, Chaetoceros muelleri was exposed to different concentrations of PPCPs $\left(0-100 \mathrm{mg} \mathrm{L}^{-1}\right)$.

\begin{tabular}{|c|c|c|c|c|c|c|c|c|}
\hline \multirow[t]{2}{*}{ Run } & \multicolumn{2}{|c|}{ Independent Factors } & \multicolumn{6}{|c|}{ Average Removal of Organic Micropollutants } \\
\hline & $\begin{array}{l}\text { Contact Time } \\
\text { (Day) }\end{array}$ & $\begin{array}{l}\text { Initial Concentration } \\
(\mathrm{mg} / \mathrm{L})\end{array}$ & $\begin{array}{l}\text { CBZ } \\
(\%)\end{array}$ & $\begin{array}{c}\mathrm{CBZ} \\
\left(\mathrm{mg} \mathrm{L}^{-1}\right)\end{array}$ & $\begin{array}{c}\text { SMT } \\
(\%)\end{array}$ & $\underset{\left(\mathrm{mg} \mathrm{L}^{-1}\right)}{\mathrm{SMT}}$ & $\begin{array}{l}\text { TRA } \\
(\%)\end{array}$ & $\begin{array}{c}\text { TRA } \\
\left(\mathrm{mg} \mathrm{L}^{-1}\right)\end{array}$ \\
\hline 1 & 0.5 & 0.2 & 14.9 & 0.029 & 12.3 & 0.024 & 13.6 & 0.027 \\
\hline 2 & 0.5 & 0.4 & 13.2 & 0.052 & 11.6 & 0.046 & 14.3 & 0.057 \\
\hline 3 & 0.5 & 0.6 & 11.4 & 0.068 & 9.2 & 0.055 & 10.5 & 0.063 \\
\hline 4 & 0.5 & 0.8 & 10.1 & 0.080 & 9.8 & 0.078 & 9.6 & 0.076 \\
\hline 5 & 0.5 & 1.0 & 8.9 & 0.089 & 9.8 & 0.098 & 8.8 & 0.088 \\
\hline 6 & 2.5 & 0.2 & 17.3 & 0.034 & 15.2 & 0.030 & 18.1 & 0.036 \\
\hline 7 & 2.5 & 0.4 & 15.2 & 0.060 & 14.5 & 0.058 & 17.3 & 0.069 \\
\hline 8 & 2.5 & 0.6 & 12.8 & 0.076 & 10.3 & 0.061 & 14.0 & 0.084 \\
\hline 9 & 2.5 & 0.8 & 12.0 & 0.096 & 10.9 & 0.087 & 13.4 & 0.107 \\
\hline 10 & 2.5 & 1.0 & 9.2 & 0.092 & 10.4 & 0.104 & 11.9 & 0.119 \\
\hline 11 & 4.5 & 0.2 & 26.3 & 0.052 & 24.5 & 0.049 & 28.2 & 0.056 \\
\hline 12 & 4.5 & 0.4 & 29.6 & 0.118 & 27.0 & 0.108 & 28.4 & 0.113 \\
\hline 13 & 4.5 & 0.6 & 26.5 & 0.159 & 24.1 & 0.144 & 24.6 & 0.147 \\
\hline 14 & 4.5 & 0.8 & 23.2 & 0.185 & 21.8 & 0.174 & 20.8 & 0.166 \\
\hline 15 & 4.5 & 1.0 & 20.7 & 0.207 & 20.4 & 0.204 & 20.5 & 0.205 \\
\hline 16 & 6.5 & 0.2 & 31.9 & 0.063 & 27.2 & 0.054 & 35.4 & 0.070 \\
\hline 17 & 6.5 & 0.4 & 30.2 & 0.120 & 25.3 & 0.101 & 32.2 & 0.128 \\
\hline 18 & 6.5 & 0.6 & 28.1 & 0.168 & 24.0 & 0.144 & 30.5 & 0.183 \\
\hline 19 & 6.5 & 0.8 & 27.8 & 0.222 & 21.5 & 0.172 & 29.6 & 0.236 \\
\hline 20 & 6.5 & 1.0 & 25.6 & 0.256 & 20.6 & 0.206 & 28.2 & 0.282 \\
\hline 21 & 8.5 & 0.2 & 35.4 & 0.070 & 31.2 & 0.062 & 35.9 & 0.071 \\
\hline 22 & 8.5 & 0.4 & 33.3 & 0.133 & 30.3 & 0.121 & 36.5 & 0.146 \\
\hline 23 & 8.5 & 0.6 & 30.2 & 0.181 & 28.1 & 0.168 & 33.0 & 0.198 \\
\hline 24 & 8.5 & 0.8 & 26.3 & 0.210 & 26.6 & 0.212 & 28.1 & 0.224 \\
\hline 25 & 8.5 & 1.0 & 23.3 & 0.233 & 25.7 & 0.257 & 27.9 & 0.279 \\
\hline 26 & 10.5 & 0.2 & 31.7 & 0.063 & 33.1 & 0.066 & 34.8 & 0.069 \\
\hline 27 & 10.5 & 0.4 & 30.4 & 0.121 & 32.8 & 0.131 & 34.8 & 0.139 \\
\hline 28 & 10.5 & 0.6 & 27.5 & 0.165 & 30.5 & 0.183 & 31.1 & 0.186 \\
\hline 29 & 10.5 & 0.8 & 26.9 & 0.215 & 27.2 & 0.217 & 29.4 & 0.235 \\
\hline 30 & 10.5 & 1.0 & 26.0 & 0.260 & 26.8 & 0.268 & 28.1 & 0.281 \\
\hline
\end{tabular}

Table 2. Response values for different independent factors in the first reactor. 
Table 3. Response values for different independent factors in the second reactor.

\begin{tabular}{|c|c|c|c|c|c|c|c|c|}
\hline \multirow[t]{2}{*}{ Run } & \multicolumn{2}{|c|}{ Independent Factors } & \multicolumn{6}{|c|}{ Average Removal of Organic Micropollutants } \\
\hline & $\begin{array}{c}\text { Contact } \\
\text { Time (Day) }\end{array}$ & $\begin{array}{l}\text { Initial Concentration } \\
(\mathrm{mg} / \mathrm{L})\end{array}$ & $\begin{array}{l}\text { CBZ } \\
(\%)\end{array}$ & $\begin{array}{c}\mathrm{CBZ} \\
\left(\mathrm{mg} \mathrm{L}^{-1}\right)\end{array}$ & $\begin{array}{l}\text { SMT } \\
(\%)\end{array}$ & $\begin{array}{c}\mathrm{SMT} \\
\left(\mathrm{mg} \mathrm{L}^{-1}\right)\end{array}$ & $\begin{array}{c}\text { TRA } \\
(\%)\end{array}$ & $\begin{array}{c}\text { TRA } \\
\left(\mathrm{mg} \mathrm{L}^{-1}\right)\end{array}$ \\
\hline 1 & 0.5 & 0.2 & 27.9 & 0.055 & 24.9 & 0.049 & 27.3 & 0.054 \\
\hline 2 & 0.5 & 0.4 & 25.2 & 0.100 & 23.3 & 0.093 & 25.6 & 0.102 \\
\hline 3 & 0.5 & 0.6 & 24.4 & 0.146 & 21.9 & 0.131 & 24.0 & 0.144 \\
\hline 4 & 0.5 & 0.8 & 23.1 & 0.184 & 21.5 & 0.172 & 23.9 & 0.191 \\
\hline 5 & 0.5 & 1.0 & 21.9 & 0.219 & 20.1 & 0.201 & 21.4 & 0.214 \\
\hline 6 & 2.5 & 0.2 & 30.3 & 0.060 & 27.9 & 0.055 & 29.5 & 0.059 \\
\hline 7 & 2.5 & 0.4 & 28.2 & 0.112 & 26.6 & 0.106 & 28.0 & 0.112 \\
\hline 8 & 2.5 & 0.6 & 25.8 & 0.154 & 22.9 & 0.137 & 25.6 & 0.153 \\
\hline 9 & 2.5 & 0.8 & 24.0 & 0.192 & 22.5 & 0.180 & 24.5 & 0.196 \\
\hline 10 & 2.5 & 1.0 & 22.2 & 0.222 & 20.8 & 0.208 & 22.4 & 0.224 \\
\hline 11 & 4.5 & 0.2 & 47.3 & 0.094 & 43.9 & 0.087 & 48.6 & 0.097 \\
\hline 12 & 4.5 & 0.4 & 50.6 & 0.202 & 46.8 & 0.187 & 51.3 & 0.205 \\
\hline 13 & 4.5 & 0.6 & 46.5 & 0.279 & 43.9 & 0.263 & 46.8 & 0.280 \\
\hline 14 & 4.5 & 0.8 & 44.2 & 0.353 & 40.3 & 0.322 & 44.1 & 0.352 \\
\hline 15 & 4.5 & 1.0 & 41.7 & 0.417 & 38.5 & 0.385 & 41.8 & 0.418 \\
\hline 16 & 6.5 & 0.2 & 61.9 & 0.123 & 56.9 & 0.113 & 61.8 & 0.123 \\
\hline 17 & 6.5 & 0.4 & 64.2 & 0.256 & 60.8 & 0.243 & 64.3 & 0.257 \\
\hline 18 & 6.5 & 0.6 & 64.1 & 0.384 & 59.5 & 0.357 & 63.0 & 0.378 \\
\hline 19 & 6.5 & 0.8 & 61.8 & 0.494 & 57.0 & 0.456 & 61.1 & 0.488 \\
\hline 20 & 6.5 & 1.0 & 59.6 & 0.596 & 56.9 & 0.569 & 60.0 & 0.600 \\
\hline 21 & 8.5 & 0.2 & 67.4 & 0.134 & 63.6 & 0.127 & 68.2 & 0.136 \\
\hline 22 & 8.5 & 0.4 & 68.3 & 0.273 & 64.3 & 0.257 & 69.4 & 0.277 \\
\hline 23 & 8.5 & 0.6 & 70.2 & 0.421 & 66.4 & 0.398 & 70.1 & 0.420 \\
\hline 24 & 8.5 & 0.8 & 66.3 & 0.530 & 61.9 & 0.495 & 66.9 & 0.535 \\
\hline 25 & 8.5 & 1.0 & 63.3 & 0.633 & 59.5 & 0.595 & 63.7 & 0.637 \\
\hline 26 & 10.5 & 0.2 & 64.7 & 0.129 & 60.8 & 0.121 & 65.0 & 0.130 \\
\hline 27 & 10.5 & 0.4 & 64.4 & 0.257 & 59.9 & 0.239 & 64.6 & 0.258 \\
\hline 28 & 10.5 & 0.6 & 65.5 & 0.393 & 60.8 & 0.364 & 65.1 & 0.390 \\
\hline 29 & 10.5 & 0.8 & 63.9 & 0.511 & 59.8 & 0.478 & 62.7 & 0.501 \\
\hline 30 & 10.5 & 1.0 & 62.0 & 0.620 & 58.2 & 0.582 & 61.9 & 0.619 \\
\hline
\end{tabular}

Table 4. Statistical analysis results for the response parameters in RSM and ANN.

\begin{tabular}{|c|c|c|c|c|c|c|c|c|c|c|c|}
\hline \multirow{3}{*}{ Reactor } & \multirow{3}{*}{ Resp. } & \multicolumn{4}{|c|}{ Optimization with RSM } & \multicolumn{6}{|c|}{ Optimization with ANN } \\
\hline & & \multirow{2}{*}{$\mathbf{R}^{2 *}$} & \multirow{2}{*}{ Adj. $R^{2}$} & \multirow{2}{*}{ Pred. $\mathbf{R}^{2}$} & \multirow{2}{*}{ SD } & \multicolumn{3}{|c|}{$\mathbf{R}^{2}$} & \multicolumn{3}{|c|}{ MSE } \\
\hline & & & & & & **Training & Valid. & Test & Training & Valid. & Test \\
\hline \multirow{3}{*}{ Reactor-1 } & $\mathrm{CBZ}$ & 0.976 & 0.954 & 0.915 & 1.73 & 0.996 & 0.996 & 0.994 & 0.664 & 0.535 & 0.532 \\
\hline & SMT & 0.928 & 0.913 & 0.897 & 2.33 & 0.997 & 0.997 & 0.995 & 0.370 & 0.333 & 0.653 \\
\hline & TRA & 0.993 & 0.987 & 0.981 & 10.2 & 0.995 & 0.994 & 0.995 & 0.742 & 0.710 & 0.863 \\
\hline \multirow{3}{*}{ Reactor-2 } & CBZ & 0.998 & 0.996 & 0.991 & 1.60 & 0.999 & 0.999 & 0.999 & 0.330 & 0.470 & 0.455 \\
\hline & SMT & 0.996 & 0.993 & 0.983 & 1.34 & 0.999 & 0.998 & 0.998 & 0.622 & 0.484 & 0.955 \\
\hline & TRA & 0.997 & 0.995 & 0.988 & 1.23 & 0.999 & 0.998 & 0.999 & 0.215 & 0.584 & 0.609 \\
\hline
\end{tabular}

$\mathrm{R}^{2 *}$ : Coefficient of determination; Adj. $\mathrm{R}^{2}$ : Adjusted $\mathrm{R}^{2}$; Pred. $\mathrm{R}^{2}$ : Prediction $\mathrm{R}^{2}$; SD: Standard deviation; and MSE: mean squared errors.

${ }^{* *}$ Training, validation and test display the divided data in different steps (training, validation and test) of the ANN process. 

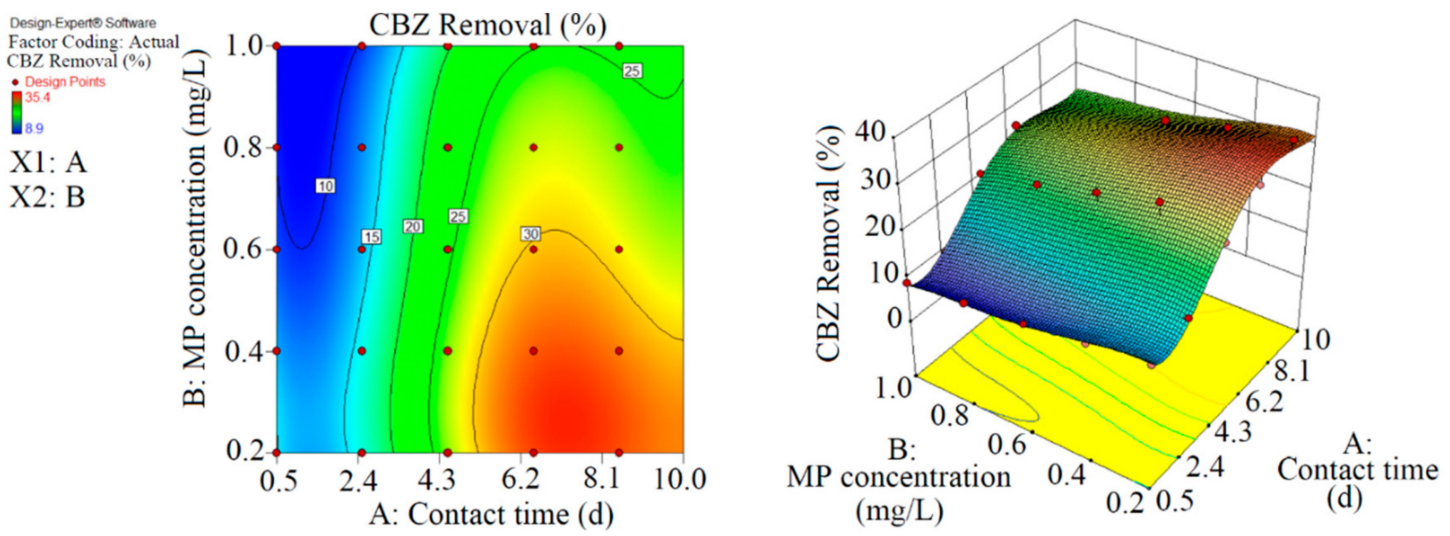

(a)
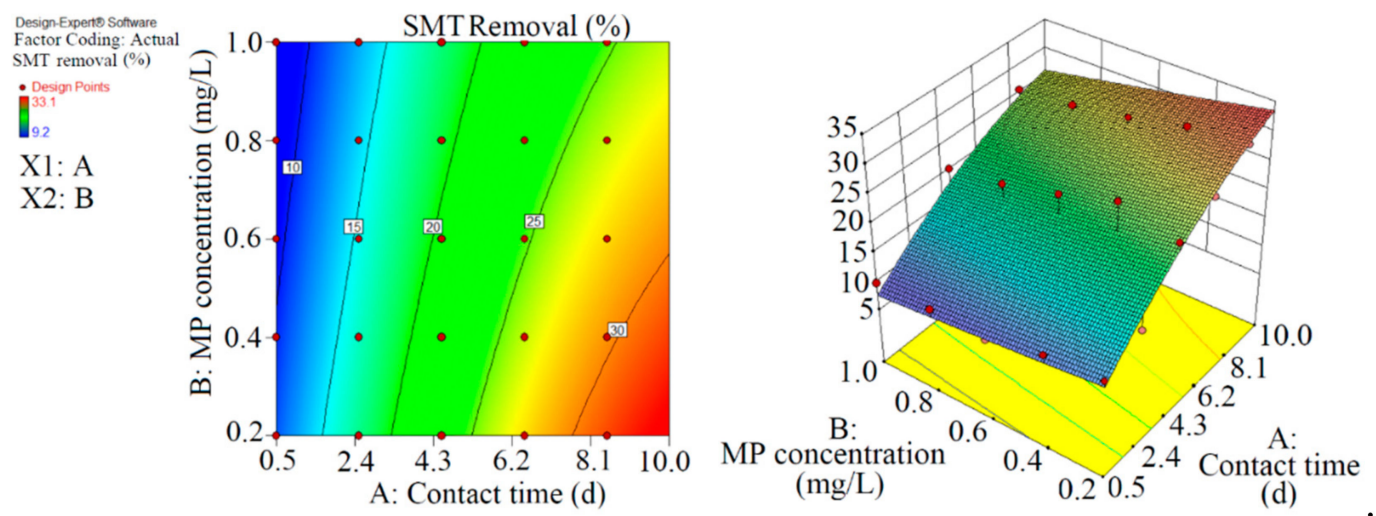

(b)
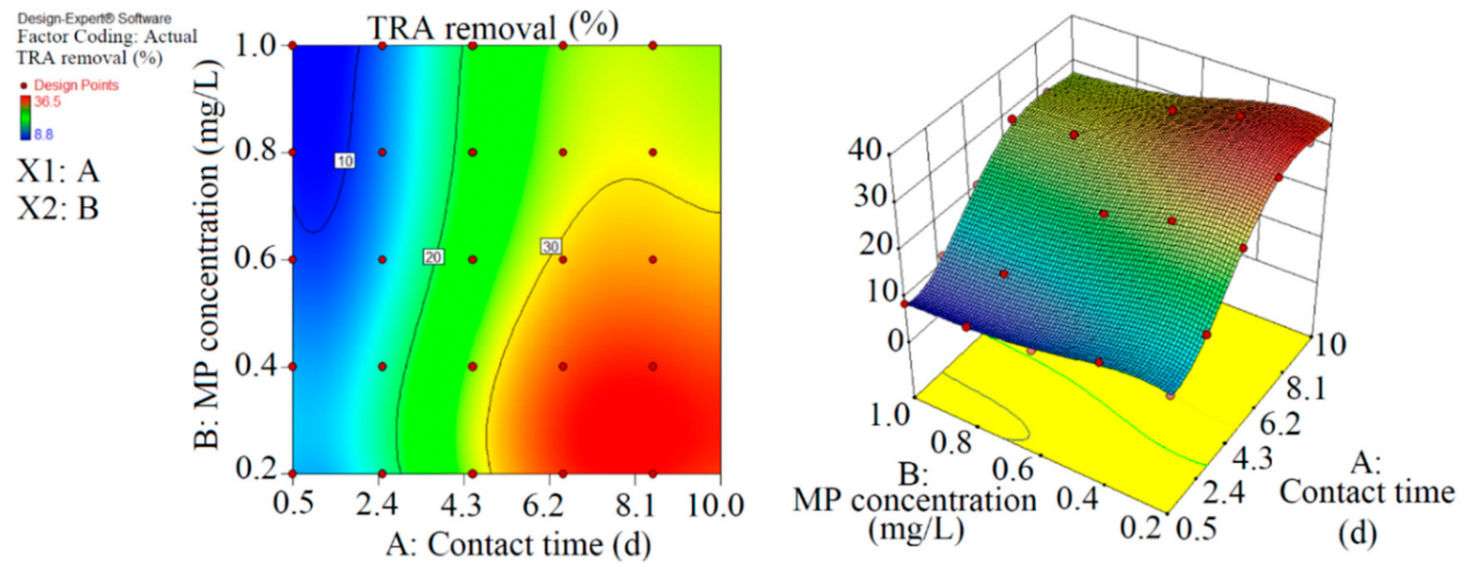

(c)

Figure 2. 3D plots for the removal of CBZ (a), SMT (b) and TRA (c) by the first reactor based on the RSM. 

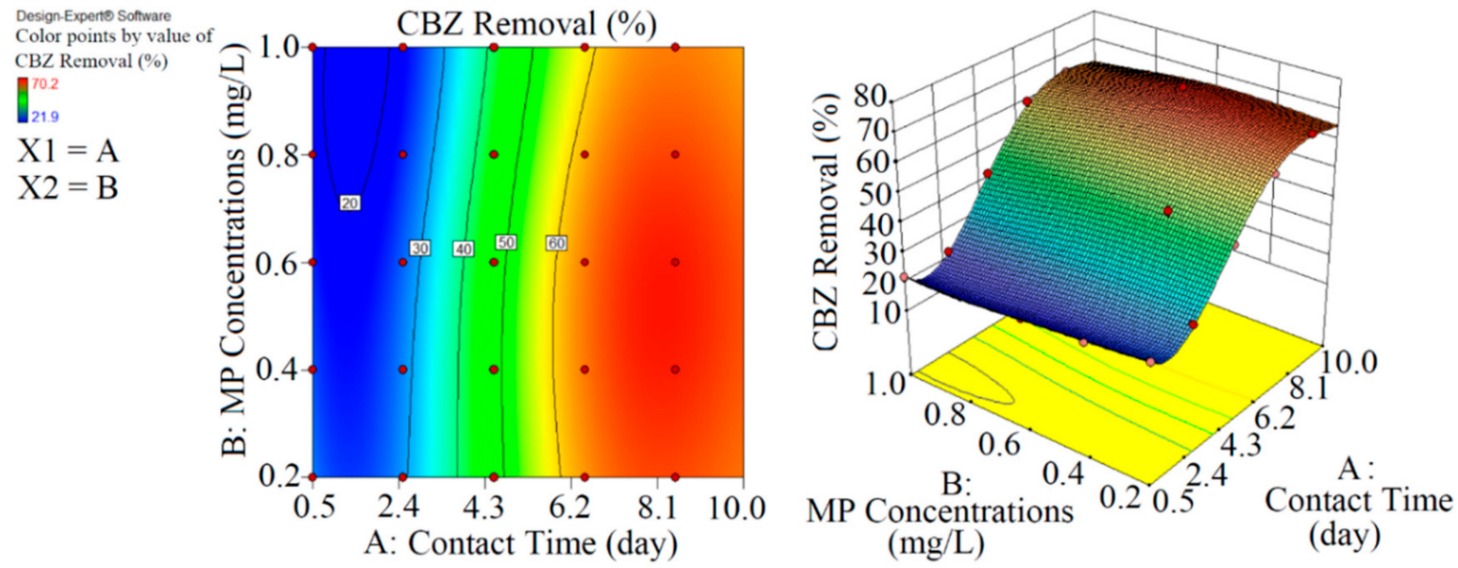

(a)
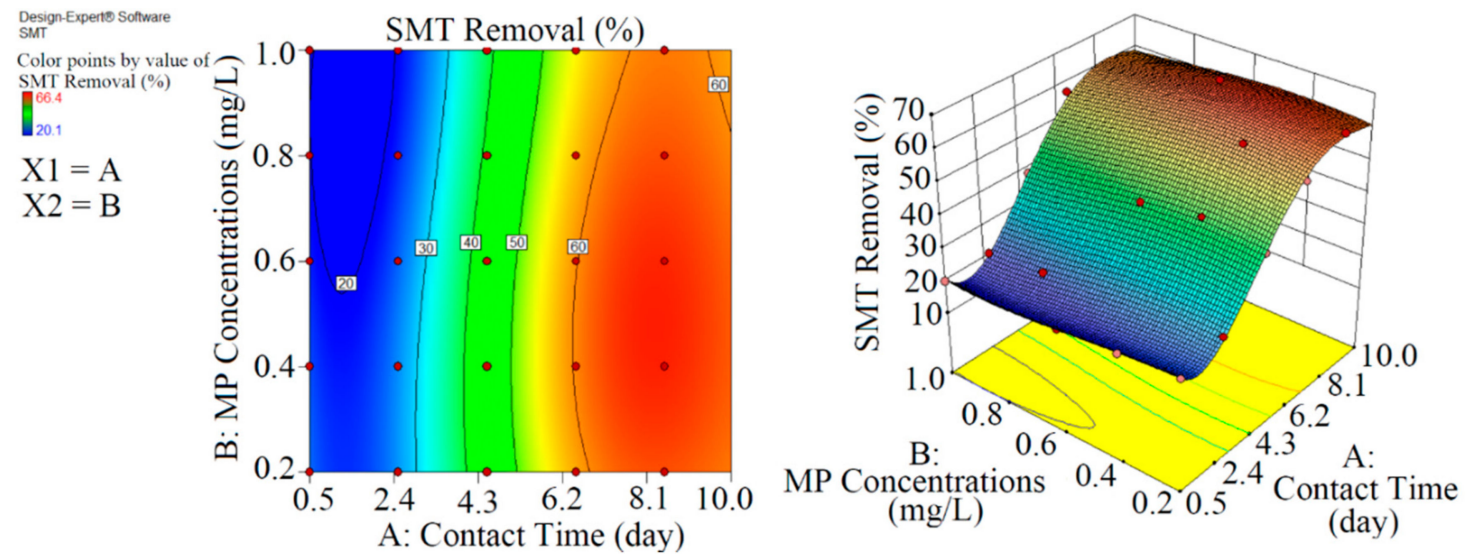

(b)

Design-Expeno Software Color points by value
TRA Removal (\%) 70.1

$\mathrm{X} 1=\mathrm{A}$

$\mathrm{X} 2=\mathrm{B}$
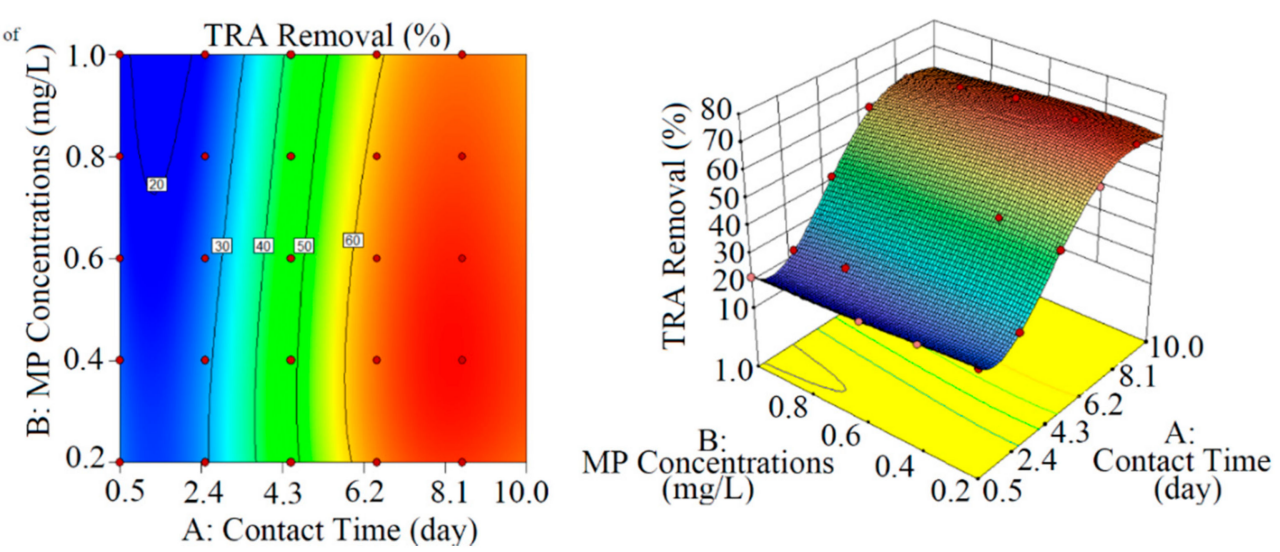

(c)

Figure 3. 3D plots for the removal of CBZ (a), SMT (b) and TRA (c) in the second reactor based on the RSM. 

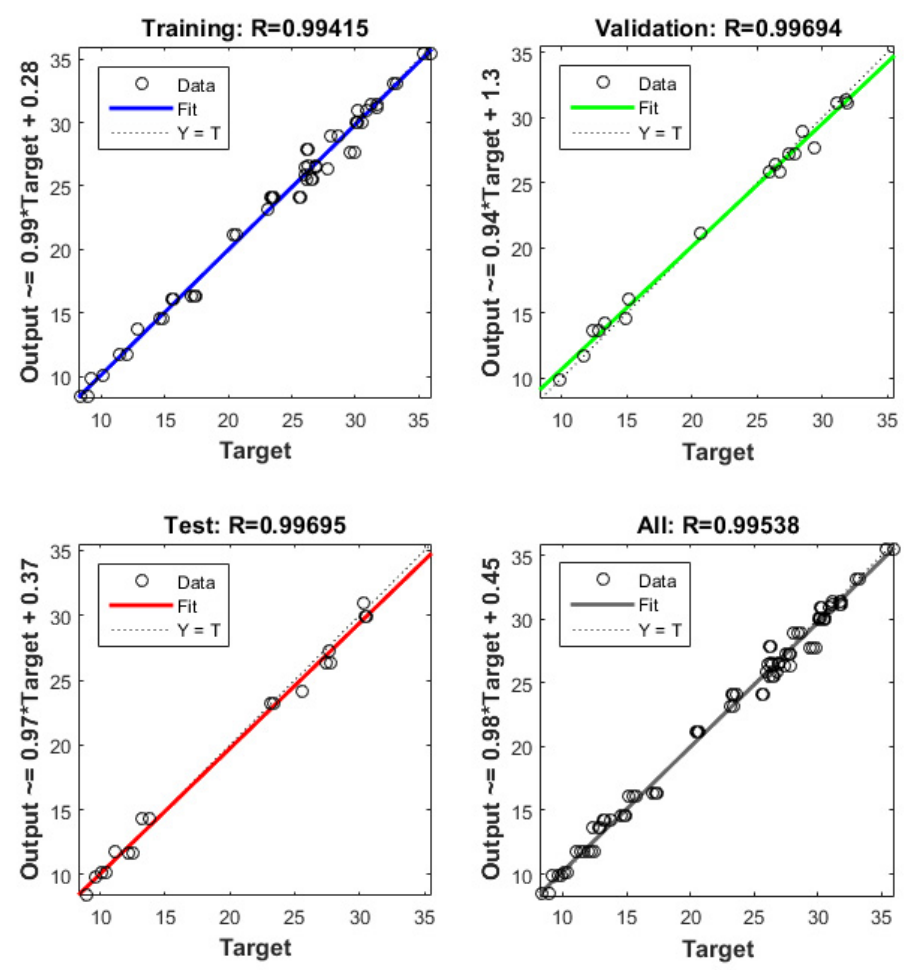

(a)
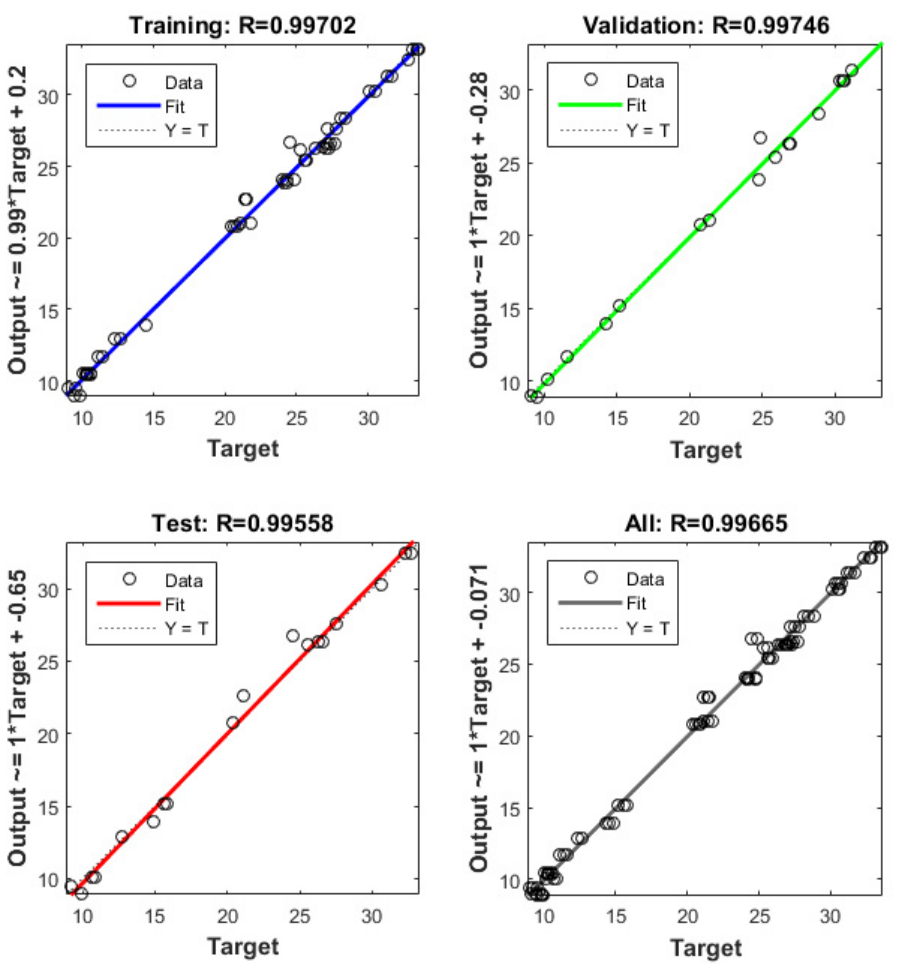

(b)

Figure 4. Cont. 

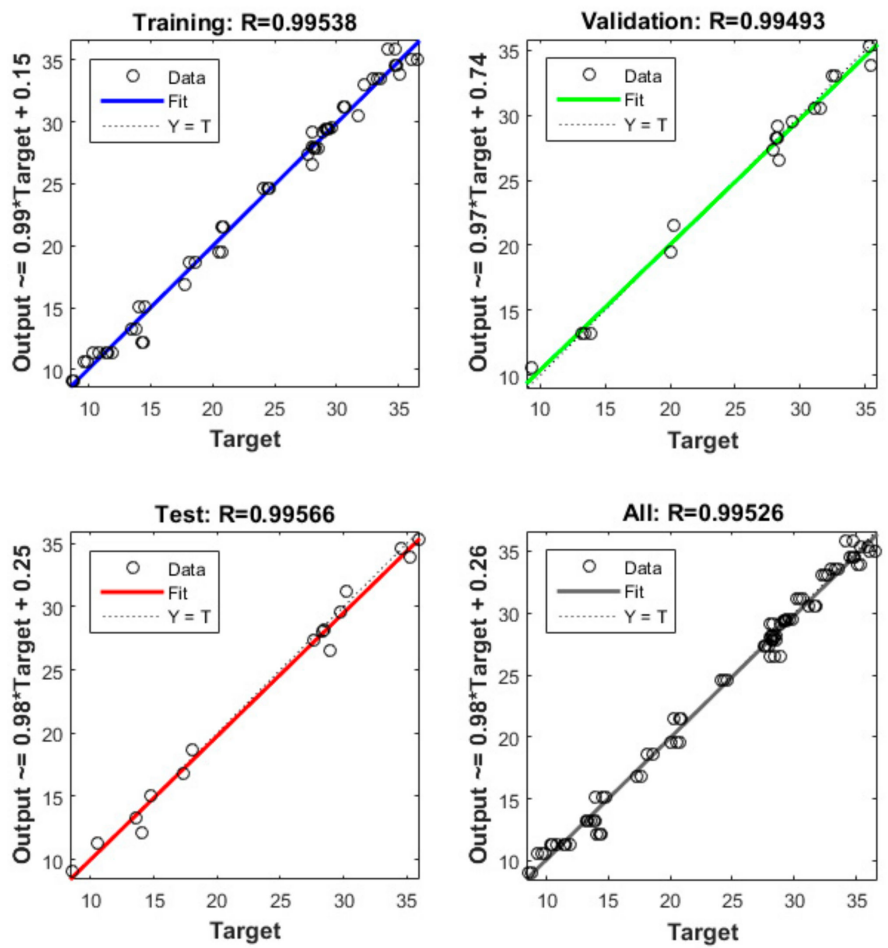

(c)

Figure 4. Model prediction versus experimental values for the removal of CBZ (a), SMT (b) and TRA (c) by the first reactor.
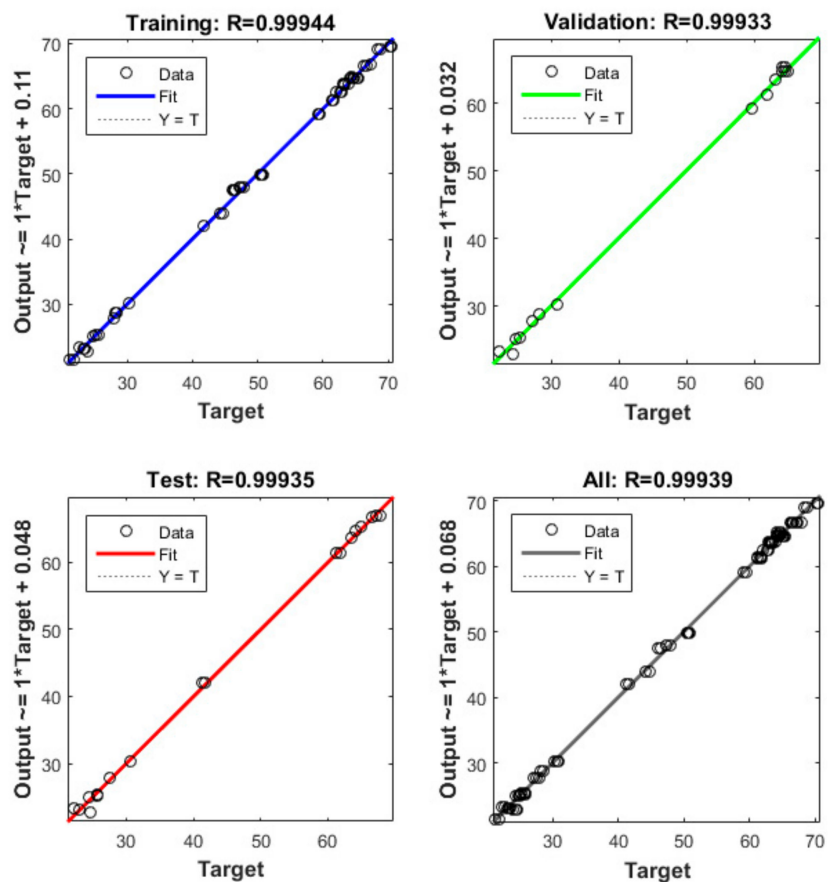

(a)

Figure 5. Cont. 

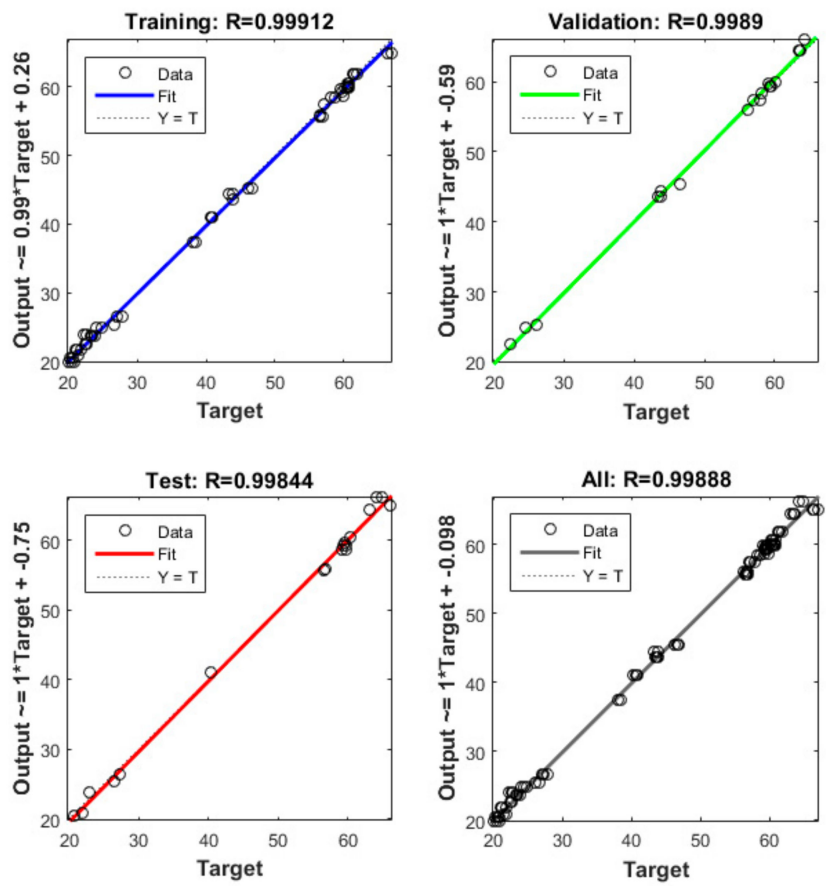

(b)
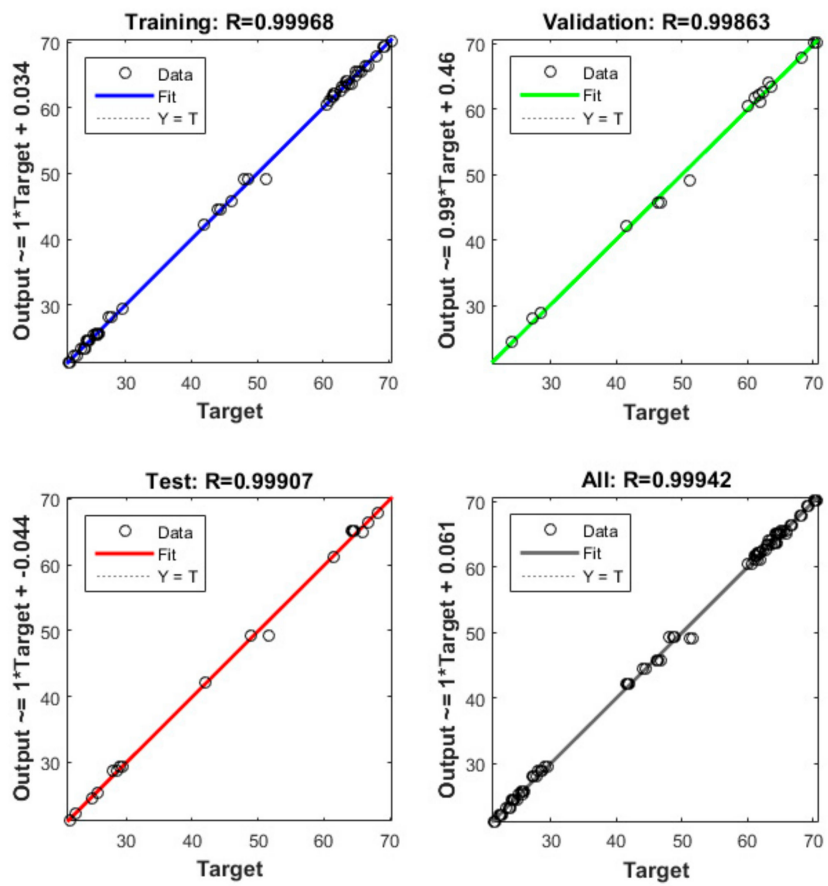

(c)

Figure 5. Model prediction versus experimental values for the removal of CBZ (a), SMT (b) and TRA (c) by the second reactor.

\subsection{Removal of Pharmaceuticals and Personal Care Products}

As shown in Figure 2 and Table 2, the maximum abatement value of CBZ, SMT and TRA were $35.4 \%\left(0.070 \mathrm{mg} \mathrm{L}^{-1}\right), 33.1 \%\left(0.066 \mathrm{mg} \mathrm{L}^{-1}\right)$ and $36.5 \%\left(0.146 \mathrm{mg} \mathrm{L}^{-1}\right)$, respec- 
tively, in the first reactor, and the initial concentrations of PPCPs $\left(\mathrm{mg} \mathrm{L}^{-1}\right)$ and contact times (day) were 0.2 and 8.5 (CBZ), 0.2 and 10.5 (SMT) and 0.4 and 8.5 (TRA). Xiong et al. [38] removed $35 \%$ and $28 \%$ of CBZ after 10 days of using Chlamydomonas mexicana and Scenedesmus obliquus, respectively. Approximately 17.3-29.3\% of SMT was removed by Scenedesmus obliquus in 12 days [39], and $45 \%$ of TRA was removed by Desmodesmus sp. RUC2 [40]. Moderate-to-low degradation was observed in the removal of CBZ and TRA through an alga-based treatment method [41]. These PPCPs are resistant to photolysis, and thus the removal efficiency of the pollutants are low [42]. Biodegradation and bioaccumulation are the main mechanisms in PPCP removal [43].

As shown in Figure 3 and Table 3, the performance of Chaetoceros muelleri in the presence of biochar (second reactor) was higher than that in the first reactor. The maximum removal rates of CBZ, SMT and TRA were $70.2 \%\left(0.421 \mathrm{mg} \mathrm{L}^{-1}\right), 66.4 \%\left(0.398 \mathrm{mg} \mathrm{L}^{-1}\right)$ and $70.1 \%\left(0.420 \mathrm{mg} \mathrm{L}^{-1}\right)$ in the second reactor, in which the initial concentration of PPCPs ( $\left.\mathrm{mg} \mathrm{L}^{-1}\right)$ and contact time (day) were 0.6 and 8.5 , respectively. These results can be explained by the adsorption of PPCPs by biochar as well as improvement in the microalgal community in the presence of biochar. Ndoun et al. [44] removed $40 \%$ of pharmaceutical by biochar at neutral $\mathrm{pH}$. Magee et al. [45] stated that biochar can absorb nutrients on its surface and attracts and immobilises algae on its surface. Liao et al. [46] stated that the microorganism communities can be enhanced in the presence of biochar. Zhu et al. [47] reported that biochar can enhance the biological degradation of pollutants.

RSM was used to optimise the removal performance of the both reactors. In terms of actual results and significant results at $p<0.5$, the final equations for the removal of CBZ, SMT and TRA by the first reactor were Equations (10)-(12), respectively.

$$
\begin{gathered}
14.08-10.97 \mathrm{~A}+53.77 \mathrm{~B}+4.97 \mathrm{~A}^{2}-0.62 \mathrm{~A}^{3}+0.02 \mathrm{~A}^{4} \\
10.57+3.67 \mathrm{~A}-5.34 \mathrm{~B}-0.11 \mathrm{~A}^{2} \\
5.06-4.03 \mathrm{~A}+94.70 \mathrm{~B}+3.17 \mathrm{~A}^{2}-0.42 \mathrm{~A}^{3}+284.85 \mathrm{~B}^{3}+0.01 \mathrm{~A}^{4}
\end{gathered}
$$

where $A$ is the contact time and $B$ is the initial concentrations of the micropollutants.

In the first reactor, the maximum removal efficiencies of CBZ $\left(33.5 \%, 0.077 \mathrm{mg} \mathrm{L}^{-1}\right)$, SMT $\left(31.0 \%, 0.071 \mathrm{mg} \mathrm{L}^{-1}\right)$ and TRA $\left(36.5 \%, 0.083 \mathrm{mg} \mathrm{L}^{-1}\right)$ were obtained at optimum contact time of 8.5 days and an initial MP concentration of $0.23 \mathrm{mg} \mathrm{L}^{-1}$ with RSM.

The final equations for the removal of CBZ, SMT and TRA in the second reactor were Equations (13)-(15), respectively.

$$
\begin{gathered}
39.53-16.56 \mathrm{~A}-42.11 \mathrm{~B}+7.46 \mathrm{~A}^{2}-7.75 \mathrm{AB}^{2}-0.89 \mathrm{~A}^{3}+0.63 \mathrm{~A}^{2} \mathrm{~B}^{2}+0.03 \mathrm{~A}^{4} \\
31.52-14.36 \mathrm{~A}-6.94 \mathrm{~B}+6.61 \mathrm{~A}^{2}-0.77 \mathrm{~A}^{3}+0.02 \mathrm{~A}^{4} \\
32.53-15.52 \mathrm{~A}+11.01 \mathrm{~B}+7.18 \mathrm{~A}^{2}-0.85 \mathrm{~A}^{3}+0.03 \mathrm{~A}^{4}
\end{gathered}
$$

In the second reactor, the maximum elimination efficiencies of CBZ $(68.9 \%, 0.330 \mathrm{mg}$ $\left.\mathrm{L}^{-1}\right)$, SMT $\left(64.8 \%, 0.331 \mathrm{mg} \mathrm{L}^{-1}\right)$ and TRA $\left(69.3 \%, 0.332 \mathrm{mg} \mathrm{L}^{-1}\right)$ were obtained at optimum contact time of 8.1 days and initial MP concentration of $0.48 \mathrm{mg} \mathrm{L}^{-1}$ through RSM. By comparing optimisation rates of both reactors, we were able to demonstrate that the biochar+marine diatom (second reactor) removed high amounts of PPCPs in a short time and at high initial MP concentrations.

As shown in Table 4 , the $R^{2}$ (for experiments) and predicted $R^{2}$ were higher than 0.9 , showing that the performance of both reactors can be optimised by the RSM. Khalid et al. [48] used the RSM in optimising wastewater treatment using Chlorella sorokiniana (microalgae). $R^{2}$ (for experiments) and predicted $R^{2}$ were higher than 0.9 , which are in line with those in the current study. The distribution of actual data versus predicted data are shown in Figures S3 and S4.

Apart from the RSM, an ANN was used in optimising the performance of both reactors. High $R^{2}$ (more than 0.99 ) and reasonable MSE (less than 0.80) in the optimisation of all 
runs (Table 4 and Figures 5 and 6) showed that the ANN could optimise the removal performance of both reactors in a logical way. Figures 5 and 6 display the plots of the experimental data in comparison with the anticipated data and indicate a reasonable distribution of points around the $\mathrm{X}=\mathrm{Y}$ line in a narrow area. The MSE values obtained by using the Levenberg-Marquardt method and selecting different functions and error histograms are shown in Figures S5 and S6 for the firth reactor and Figures S7 and S8 for the second reactor. Training was completed after 22 (CBZ), 19 (SMT) and 21 (TRA) epochs in the first reactor and after 27 (CBZ), 8 (SMT) and 31 (TRA) epochs in the second reactors. These results showed that the ANN model was effectively trained at the end of the training phase [4].

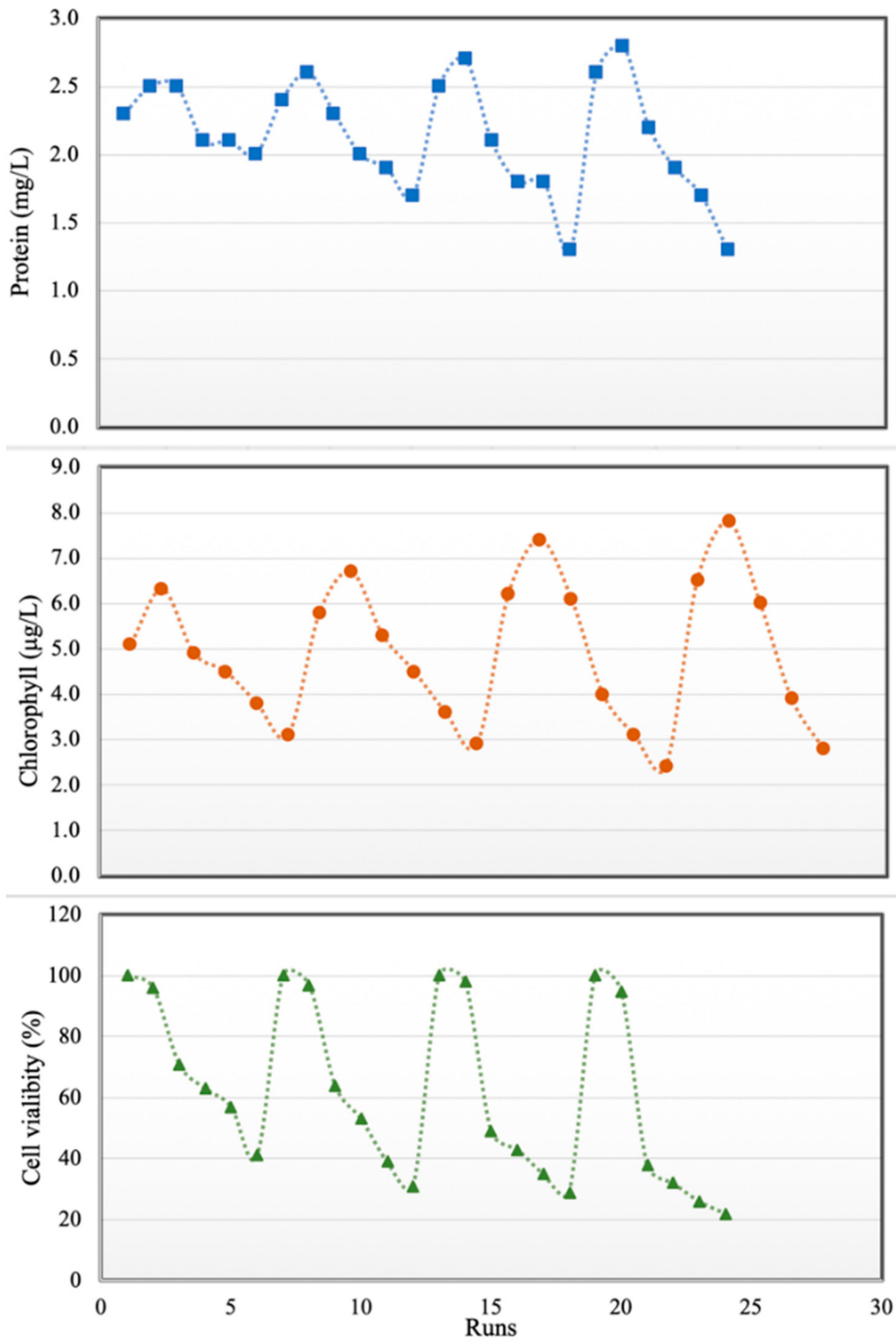

Figure 6. Effects of PPCPs on proteins (top), total chlorophyll (middle) and cell viability (bottom). 


\subsection{Effects of Pharmaceuticals and Personal Care Products Concentrations on Chaetoceros Muelleri}

The combined effects of some pharmaceutical micropollutants on marine diatom have not been reported in previous studies. Therefore, in the second part of this study, water was contaminated with CBZ, SMT and TRA with total PPCP concentrations of $0-100 \mathrm{mg} \mathrm{L}^{-1}$. As shown in Figure 6, protein content and total chlorophyll increased with PPCP concentration up to $40 \mathrm{mg} / \mathrm{L}$, and PPCP concentrations of up to $40 \mathrm{mg} / \mathrm{L}$ did not have any significant effect on cell viability. Xiong et al. [38] reported that increase in chlorophyll content may enable microalgae to reduce the accumulated reactive oxygen species in chloroplasts in the presence of low amounts of PPCPs. Another reason for increases in protein content and total chlorophyll in diatoms in the presence of low PPCP concentrations is the inductive influence of pharmaceutically active compounds on cells (hormesis) [49]. In the current study, when PPCP concentration exceeded $40 \mathrm{mg} / \mathrm{L}$, cell viability, protein content and total chlorophyll decreased. This result is in line with those of Saygideger and Okkay [25]. Tsiaka et al. [27] stated that algae treated for 24, 48, 72 and $96 \mathrm{~h}$ with carbamazepine (more than $10 \mathrm{mg} \mathrm{L}^{-1}$ ) showed an increasing in levels of carotenoids. Zhang et al. [49] expressed that low concentrations of some pharmaceuticals (diclofenac and ciprofloxacin less than $30 \mathrm{mg} \mathrm{L}^{-1}$ ) have a positive impact on chlorophyll $a$ accumulation and increasing algae growth. Diclofenac at concentration of more than $40 \mathrm{mg} \mathrm{L}^{-1}$ had a $70 \%$ inhabitation rate for Chlorellapyrenoidosa growth (microalgae). These organic contaminants may cause interference both with the synthesis of protochlorophyll and its subsequent conversion to chlorophyll [26] in high concentrations. Furthermore, long time contact (96 h) with a high amount of PPCP had more negative effects on microalgae during our study. In this study minimum cell viability $(22 \%)$, chlorophyll $\left(1.5 \mu \mathrm{g} \mathrm{L}^{-1}\right)$ and protein content $(1.3 \mathrm{mg}$ $\mathrm{L}^{-1}$ ) of Chaetoceros muelleri were recorded at the contact time $(96 \mathrm{~h})$ and micropollutant concentration (100 $\left.\mathrm{mg} \mathrm{L}^{-1}\right)$. Azevedo et al. [50] expressed that the inhibitory impact of ciprofloxacin on the growth of cyanobacteria was accentuated after $48 \mathrm{~h}$. The drug should penetrate the cell for its act, it means taking time to get maximum effects of PPCPs on the cell. Changes in protein, chlorophyll contents and cell viability are shown in Figure 6 . The summary of the experiments for determining the impact of PPCPs on microalgae is shown in Table 5 .

Table 5. Experiments for examining the effects of PPCPs on microalgae.

\begin{tabular}{|c|c|c|c|c|c|}
\hline Runs & Time (Day) & $\begin{array}{c}\text { PPCPs } \\
\text { Concentrations } \\
\left(\mathrm{mg} \mathrm{L}^{-1}\right)\end{array}$ & Runs & Time (Day) & $\begin{array}{c}\text { PPCPs } \\
\text { Concentrations } \\
\left(\mathrm{mg} \mathrm{L}^{-1}\right)\end{array}$ \\
\hline 1 & 24 & 0 & 13 & 72 & 0 \\
\hline 2 & 24 & 20 & 14 & 72 & 20 \\
\hline 3 & 24 & 40 & 15 & 72 & 40 \\
\hline 4 & 24 & 60 & 16 & 72 & 60 \\
\hline 5 & 24 & 80 & 17 & 72 & 80 \\
\hline 6 & 24 & 100 & 18 & 72 & 100 \\
\hline 7 & 48 & 0 & 19 & 96 & 0 \\
\hline 8 & 48 & 20 & 20 & 96 & 20 \\
\hline 9 & 48 & 40 & 21 & 96 & 40 \\
\hline 10 & 48 & 60 & 22 & 96 & 60 \\
\hline 11 & 48 & 80 & 23 & 96 & 80 \\
\hline 12 & 48 & 100 & 24 & 96 & 100 \\
\hline
\end{tabular}




\subsection{Adsorption Isotherm Study for the Removal of Pharmaceuticals and Personal Care Products by} Biochar

Based on the biochar characteristics analysis, the BET surface area $\left(\mathrm{m}^{2} \mathrm{~g}^{-1}\right)$, Langmuir surface area $\left(\mathrm{m}^{2} \mathrm{~g}^{-1}\right)$, micropore area $\left(\mathrm{m}^{2} \mathrm{~g}^{-1}\right)$ and micropore value $(\mathrm{cc} / \mathrm{g})$ were 702,1171 , 301 and 0.19 , respectively.

Langmuir isotherm was reached by plotting $1 /(x / m)$ against $\left(1 / C_{e}\right)$ and using Equation (16). Based on the Langmuir isotherm (Table 6), the maximum adsorption capacities $\left(\mathrm{q}_{\mathrm{m}}, \mathrm{mg} \mathrm{g}^{-1}\right.$ ) were 16.6 (CBZ), 13.9 (SMT) and 9.7 (TRA), and the $R^{2}$ values were 0.918 , 0.904 and 0.902 , respectively. Ndoun et al. [44] reported a $\mathrm{q}_{\mathrm{m}}$ value of $17 \mathrm{mg} \mathrm{g}^{-1}$, and Kim et al. [51] reported a value of 0.99 for the removal of PPCPs by biochar, which are nearly equal to the findings of the current study.

$$
\frac{x}{m}=\frac{a b C_{e}}{\left(1+b C_{e}\right)}
$$

where $x / m$ is the adsorbed the mass of the adsorbate $\left(\mathrm{mg} \mathrm{g}^{-1}\right), a$ and $b$ are empirical constants and $C_{e}$ denotes the adsorbate concentration after the adsorption process $\left(\mathrm{mg} \mathrm{L}^{-1}\right)$.

Table 6. Langmuir and Freundlich isotherms study for CBZ, AMT and TRA removal by biochar.

\begin{tabular}{ccccccc}
\hline \multirow{2}{*}{ Parameters } & \multicolumn{3}{c}{ Langmuir Isotherm } & \multicolumn{3}{c}{ Freundlich Isotherm } \\
\cline { 2 - 7 } & $\begin{array}{c}\mathbf{Q}_{\mathbf{m}} \\
(\mathbf{m g} / \mathbf{g})\end{array}$ & $\mathbf{b}$ & $\mathbf{R}^{\mathbf{2}}$ & $\begin{array}{c}\mathbf{K}_{\mathbf{f}} \\
\left(\mathbf{m g} / \mathbf{g}(\mathbf{L} / \mathbf{m g})^{\mathbf{1 / n}}\right)\end{array}$ & $\mathbf{1 / n}$ & $\mathbf{R}^{\mathbf{2}}$ \\
\hline CDZ & 16.6 & 0.10 & 0.918 & 0.39 & 0.69 & 0.921 \\
\hline SMT & 13.9 & 0.23 & 0.904 & 0.31 & 0.42 & 0.913 \\
\hline TRA & 9.7 & 0.09 & 0.902 & 0.26 & 0.71 & 0.931 \\
\hline
\end{tabular}

Freundlich isotherm factors were obtained by plotting $\log (\mathrm{x} / \mathrm{m})$ against $\log \left(\mathrm{C}_{\mathrm{e}}\right)$. The liner equation for the calculation parameters of the Freundlich isotherm is provided in Equation (17). Based on the Freundlich isotherm, the maximum adsorption capacities $\left(\mathrm{K}_{\mathrm{f}}, \mathrm{mg} \mathrm{g}^{-1}\right)$ were 0.39 (CBZ), 0.31 (SMT) and 0.26 (TRA), and the $R^{2}$ values were 0.921 , 0.913 and 0.931 , respectively. Ndoun et al. [44] reported a $\mathrm{K}_{\mathrm{f}}$ value of $0.33 \mathrm{mg} \mathrm{g}^{-1}$, and Kim et al. [51] reported a value of 0.93 for the removal of PPCPs by biochar, which are consistent with the findings of the current study. Therefore, both isotherms could explain PPCP removal by biochar.

$$
\frac{x}{m}=K_{f} C_{e}^{1 / n}
$$

where $x / m$ is the adsorbed mass of the adsorbate $\left(\mathrm{mg} \mathrm{g}^{-1}\right), K_{f}$ is the capacity factor, $1 / n$ is the intensity parameter and $C_{e}$ is the adsorbate concentration in equilibrium after the adsorption process $\left(\mathrm{mg} \mathrm{L}^{-1}\right)$.

\section{Conclusions}

High concentrations of persistent PPCPs may affect the bioremediation process of marine microalgae; consequently, integrated biochar and Chaetoceros muelleri may improve elimination performance. Two photobioreactors were employed, one of which comprised Chaetoceros muelleri (first reactor) and another comprised biochar and Chaetoceros muelleri (second reactor). The vital findings of the current research are as follows:

1. During running the first photobioreactor, the maximum abatement of CBZ, SMT and TRA was $90.5 \%, 93.5 \%$ and $88.7 \%$, respectively, $35.4 \%\left(0.070 \mathrm{mg} \mathrm{L}^{-1}\right), 33.1 \%(0.066 \mathrm{mg}$ $\left.\mathrm{L}^{-1}\right)$ and $36.5 \%\left(0.146 \mathrm{mg} \mathrm{L}^{-1}\right)$, respectively, on the contact time 8.5 to 10.50 days and the initial concentration of PPCPs of 0.20 to $0.40 \mathrm{mg} \mathrm{L}^{-1}$.

2. The optimum removal of CBZ, SMT and TRA was $70.2 \%\left(0.421 \mathrm{mg} \mathrm{L}^{-1}\right), 66.4 \%$ $\left(0.398 \mathrm{mg} \mathrm{L}^{-1}\right)$ and $70.1 \%\left(0.420 \mathrm{mg} \mathrm{L}^{-1}\right)$ during running the second reactor, re- 
spectively, on the contact time 8.5 days and the initial concentration of PPCPs of $0.60 \mathrm{mg} \mathrm{L}^{-1}$.

3. Based on the optimisation with RSM, the performance of the second reactor was much more than the first reactor. And maximum removal of CBZ $\left(68.9 \%, 0.330 \mathrm{mg} \mathrm{L}^{-1}\right)$, SMT $\left(64.8 \%, 0.331 \mathrm{mg} \mathrm{L}^{-1}\right)$ and TRA $\left(69.3 \%, 0.332 \mathrm{mg} \mathrm{L}^{-1}\right)$ was achieved at optimum contact time $(8.1 \mathrm{~d})$, and initial concentrations of MPs $\left(0.48 \mathrm{mg} \mathrm{L}^{-1}\right)$.

4. By increasing the PPCPs concentration up to $40 \mathrm{mg} \mathrm{L}^{-1}$, protein and chlorophyll of marine diatom were increased. However, the protein, chlorophyll and cell viability were decreased by increasing the PPCP concentration from $40 \mathrm{mg} \mathrm{L}^{-1}$ to $100 \mathrm{mg} \mathrm{L}^{-1}$. 5. The $R^{2}$ values and MSE values were $>0.99$ and $<0.90$ during optimising removal of PPCPs with both reactors by ANN.

6. Both Freundlich and Langmuir isotherms are proper for clarifying PPCPs adsorption by biochar.

Supplementary Materials: The following are available online at https:/ /www.mdpi.com/2076-260 7/9/1/4/s1; Figure S1: Cultivation microalgae before treatments, Figure S2: The schematic of ANN model, Figure S3: Data distribution for removal of CBZ (a), SMT (b) and TRA (c) by the first reactor; RSM model, Figure S4: Data distribution for removal of CBZ (a), SMT (b) and TRA (c) by the second reactor; RSM model, Figure S5: The MSE plots during modeling with ANN for removal of CBZ (a), SMT (b) and TRA (c) by the first reactor, Figure S6: The error histogram during modeling with ANN for removal of CBZ (a), SMT (b) and TRA (c) by the first re-actor, Figure S7: The MSE plots during modeling with ANN for removal of CBZ (a), SMT (b) and TRA (c) by the first reactor, and Figure S8: The error histogram during modeling with ANN for removal of CBZ (a), SMT (b) and TRA (c) by the first re-actor.

Author Contributions: Conceptualization and Methodology, A.M. and M.B.; Software, A.M., R.A.K., H.F. and Z.L.; writing—original draft preparation, A.M. and M.B.; formal analysis: R.A.K., H.F. and Z.L. All authors have read and agreed to the published version of the manuscript.

Funding: This research received no external funding.

Conflicts of Interest: The authors declare no conflict of interest.

\section{References}

1. Xiao, L.; Liu, J.; Ge, J. Dynamic game in agriculture and industry cross-sectoral water pollution governance in developing countries. Agric. Water Manag. 2021, 243, 106417. [CrossRef]

2. Azaroff, A.; Miossec, C.; Lanceleur, L.; Guyoneaud, R.; Monperrus, M. Priority and emerging micropollutants distribution from coastal to continental slope sediments: A case study of Capbreton Submarine Canyon (North Atlantic Ocean). Sci. Total Environ. 2020, 703, 135057. [CrossRef]

3. Shao, Y.; Chen, Z.; Hollert, H.; Zhou, S.; Deutschamann, B.; Seiler, T.B. Toxicity of 10 organic micropollutants and their mixture: Implications for aquatic risk assessment. Sci. Total Environ. 2019, 666, 1273-1282. [CrossRef]

4. Mojiri, A.; Kazeroon, R.A.; Gholami, A. Cross-Linked Magnetic Chitosan/Activated Biochar for Removal of Emerging Micropollutants from Water: Optimization by the Artificial Neural Network. Water 2019, 11, 551. [CrossRef]

5. Vakili, A.; Mojiri, A.; Kindaichi, T.; Cagnetta, G.; Yuan, J.; Wang, B.; Giwa, A.S. Cross-linked chitosan/zeolite as a fixed-bed column for organic micropollutants removal from aqueous solution, optimization with RSM and artificial neural network. J. Environ. Manag. 2019, 250, 109434. [CrossRef] [PubMed]

6. Kokkinos, P.; Mantzavinos, D.; Venieri, D. Current Trends in the Application of Nanomaterials for the Removal of Emerging Micropollutants and Pathogens from Water. Molecules 2020, 25, 2016. [CrossRef] [PubMed]

7. Yentür, G.; Dükkanc1, M. Synthesis of Visible-Light heterostructured photocatalyst of Ag/AgCl deposited on (0 40$)$ facet of monoclinic $\mathrm{BiVO}_{4}$ for efficient carbamazepine photocatalytic removal. Appl. Surf. Sci. 2020, 531, 147322. [CrossRef]

8. Li, N.; Liu, Q.; Zhou, G.Q.; Dai, M.X.; Kong, Q. Contaminant removal and microorganism response of activated sludge in sulfamethazine wastewater treatment. Int. Biodeterior. Biodegrad. 2019, 143, 104705. [CrossRef]

9. Kolahi-Ahari, S.; Deiminiat, B.; Rounaghi, G.H. Modification of a pencil graphite electrode with multiwalled carbon nanotubes capped gold nanoparticles for electrochemical determination of tramadol. J. Electroanal. Chem. 2020, 862, 113996. [CrossRef]

10. Kostanjevecki, P.; Petric, I.; Loncar, J.; Smital, T.; Ahel, M.; Terzic, S. Aerobic biodegradation of tramadol by pre-adapted activated sludge culture: Cometabolic transformations and bacterial community changes during enrichment. Sci. Total Environ. 2019, 687, 858-866. [CrossRef] [PubMed] 
11. Mojiri, A.; Vakili, M.; Farraji, H.; Aziz, S.Q. Combined ozone oxidation process and adsorption methods for the removal of acetaminophen and amoxicillin from aqueous solution; kinetic and optimisation. Environ. Technol. Innov. 2019, 15, 100404. [CrossRef]

12. Shakerian, F.; Zhao, J.; Li, S.P. Recent development in the application of immobilized oxidative enzymes for bioremediation of hazardous micropollutants-A review. Chemosphere 2020, 239, 124716. [CrossRef] [PubMed]

13. Myhead, E.; Silkina, A.; Llewellyn, C.A.; Fuentes-Grünewald, C. Comparing Nutrient Removal from Membrane Filtered and Unfiltered Domestic Wastewater Using Chlorella vulgaris. Biology 2020, 7, 12. [CrossRef] [PubMed]

14. García-Galán, M.J.; Matamoros, V.; Uggetti, E.; Díez-Montero, R.; García, J. Removal and environmental risk assessment of contaminants of emerging concern from irrigation waters in a semi-closed microalgae photobioreactor. Environ. Res. 2020, 110278. [CrossRef] [PubMed]

15. Robledo-Padilla, F.; Aquines, O.; Silva-Núñez, A.; Alemán-Nava, G.S.; Castillo-Zacarías, C.; Ramirez-Mendoza, R.A.; Zavala-Yoe, R.; Iqbal, H.M.N.; Parra-Saldívar, R. Evaluation and Predictive Modeling of Removal Condition for Bioadsorption of Indigo Blue Dye by Spirulina platensis. Microorganisms 2020, 8, 82. [CrossRef] [PubMed]

16. Jiménez-Bambague, E.M.; Madera-Parra, C.A.; Ortiz-Escobar, A.C.; Morales-Acosta, P.A.; Peña-Salamanca, E.J.; MachucaMartínez, F. High-rate algal pond for removal of pharmaceutical compounds from urban domestic wastewater under tropical conditions. Case study: Santiago de Cali, Colombia. Environ. Sci. Technol. 2020, 82, 1031-1043. [CrossRef]

17. Minggat, E.; Roseil, W.; Tanaka, Y. Nutrient Absorption and Biomass Production by the Marine Diatom Chaetoceros muelleri: Effects of Temperature, Salinity, Photoperiod, and Light Intensity. J. Ecol. Eng. 2020, 22, 231-240. [CrossRef]

18. Wang, X.W.; Liang, J.R.; Luo, C.S.; Chen, C.P.; Gao, Y.H. Biomass, total lipid production, and fatty acid composition of the marine diatom Chaetoceros muelleri in response to different $\mathrm{CO}_{2}$ levels. Bioresour. Technol. 2014, 161, 124-130. [CrossRef]

19. Karthikeyan, P.; Manimaran, K.; Sampathkumar, P.; Rameshkumar, L. Growth and nutrient removal properties of the diatoms, Chaetoceros curvisetus and C. simplex under different nitrogen sources. Appl. Water Sci. 2013, 3, 49-55. [CrossRef]

20. Mulla, S.I.; Bharagava, R.N.; Belhaj, D.; Ameen, F.; Saratale, G.D.; Gupta, S.K.; Tyagi, S.; Patil, K.S.; Hu, A. A Review of Micropollutant Removal by Microalgae. In Application of Microalgae in Wastewater Treatment, Volume 1: Domestic and Industrial Wastewater Treatment; Gupta, S.K., Bux, F., Eds.; Springer: Berlin/Heidelberg, Germany, 2019. [CrossRef]

21. Xiang, W.; Zhang, X.; Chen, J.; Zou, W.; He, F.; Hu, X.; Tsang, D.C.W.; Ok, Y.S.; Gao, B. Biochar technology in wastewater treatment: A critical review. Chemosphere 2020, 252, 126539. [CrossRef]

22. Pokharel, A.; Acharya, B.; Farooque, A. Biochar-Assisted Wastewater Treatment and Waste Valorization. In Applications of Biochar for Environmental Safety; Abdelhafez, A., Abbas, M., Eds.; IntechOpen: London, UK, 2020. [CrossRef]

23. Gorovtsov, A.V.; Minkina, T.M.; Mandzhieva, S.S.; Perelomov, L.V.; Soja, G.; Zamulina, I.V.; Rajput, V.D.; Sushkova, S.N.; Mohan, D.; Yao, J. The mechanisms of biochar interactions with microorganisms in soil. Environ. Geochem. Health 2020, 42, $2495-2518$. [CrossRef] [PubMed]

24. Miazek, K.; Brozek-Pluska, B. Effect of PHRs and PCPs on Microalgal Growth, Metabolism and Microalgae-Based Bioremediation Processes: A Review. Int. J. Mol. Sci. 2019, 20, 2492. [CrossRef] [PubMed]

25. Saygideger, S.D.; Okkay, O. Effect of 2,4-Dichlorophenoxyacetic acid on growth, protein and chlorophyll-a content of Chlorella vulgaris and Spirulina platensis cells. J. Environ. Biol. 2008, 29, 175-178. [PubMed]

26. Zhang, W.; Zhang, M.; Lin, K.; Sun, W.; Xiong, B.; Guo, M.; Cui, X.; Fu, R. Eco-toxicological effect of Carbamazepine on Scenedesmus obliquus and Chlorella pyrenoidosa. Environ. Toxicol. Pharmacol. 2012, 33, 344-352. [CrossRef] [PubMed]

27. Tsiaka, P.; Tsarpali, V.; Ntaikou, I.; Kostopoulou, M.N.; Lyberatos, G.; Dailianis, S. Carbamazepine-mediated pro-oxidant effects on the unicellular marine algal species Dunaliella tertiolecta and the hemocytes of mussel Mytilus galloprovincialis. Ecotoxicology 2013, 22, 1208-1220. [CrossRef] [PubMed]

28. Mojiri, A.; Zhou, J.; Vakili, M.; Le, H.V. Removal performance and optimisation of pharmaceutical micropollutants from synthetic domestic wastewater by hybrid treatment. J. Contam. Hydrol. 2020, 235, 103736. [CrossRef]

29. Schmidtová, Z.; Kodešová, R.; Grabicová, K.; Kočárek, M.; Fér, M.; Švecová, H.; Klement, A.; Nikodem, A.; Grabic, R. Competitive and synergic sorption of carbamazepine, citalopram, clindamycin, fexofenadine, irbesartan and sulfamethoxazole in seven soils J. Contam. Hydrol. 2020, 234, 103680. [CrossRef]

30. González-González, L.M.; Eltanahy, E.; Schenk, P.M. Assessing the fertilizing potential of microalgal digestates using the marine diatom Chaetoceros muelleri. Algal Res. 2019, 41, 101534. [CrossRef]

31. Batista, I.; Garcia, A.B.; Dalen, P.V.; Kamermans, P.; Verdegem, M.; Smaal, A.C. Culturing Chaetoceros muelleri using simplified media with different $\mathrm{N}$ sources: Effects on production and lipid content. Eur. J. Phycol. 2015, 50, 92-99. [CrossRef]

32. Sue, G.; Jiao, K.; Chang, J.; Li, Z.; Guo, X.; Sun, Y.; Zeng, X.; Lu, Y.; Lin, L. Enhancing total fatty acids and arachidonic acid production by the red microalgae Porphyridium purpureum. Bioresour. Bioprocess. 2016, 3, 33. [CrossRef]

33. Dolatabadi, M.; Ahmadzadeh, S. A reapid and efficient removal of approach for degradation of metformin in pharmaceutical wastewater using elctro-Fenton process; optimisation by response surface methodology. Water Sci. Technol. 2019, 80, 685-694. [CrossRef] [PubMed]

34. Dolatabadi, M.; Mehrabpour, M.; Esfandyari, M.; Ahmadzadeh, S. Adsorption of tetracycline antibiotic onto modified zeolite: Experimental investigation and modeling. MethodsX 2020, 7, 100886. [CrossRef] [PubMed]

35. Chia, S.R.; Chew, K.W.; Zaid, H.F.M.; Chu, D.T.; Tao, Y.; Show, P.L. Microalgal Protein Extraction from Chlorella vulgaris FSP-E using Triphasic Partitioning Technique with Sonication. Front. Bioeng. Biotechnol. 2019, 7, 369. [CrossRef] [PubMed] 
36. Ma, M.; Liu, R.; Qu, J.; Jefferson, W. Effects and mechanisms of pre-chlorination on Microcystis aeruginosa removal by alum coagulation: Significance of the released intracellular organic matter. Sep. Purif. Technol. 2012, 19-25. [CrossRef]

37. Namasivayam, S.K.R.; Jayakumar, D.; Kumar, V.R.; Bharani, R.S.A. Anti Bacterial and Anti Cancerous Biocompatible Silver Nanoparticles Synthesised from the Cold Tolerant Strain of Spirulina platensis. Res. J. Pharm. Technol. $2014,7,1404-1412$. [CrossRef]

38. Xiong, J.Q.; Kurade, M.B.; Abou-Shanab, R.A.I.; Ji, M.K.; Choi, J.; Kim, J.O.; Jeonh, B.H. Biodegradation of carbamazepine using freshwater microalgae Chlamydomonas mexicana and Scenedesmus obliquus and the determination of its metabolic fate. Bioresour. Technol. 2016, 205, 183-190. [CrossRef]

39. Xiong, J.Q.; Kim, S.J.; Kurade, M.B.; Govindwar, S.; Abou-Shanab, R.A.I.; Kim, J.R.; Roh, H.S.; Khan, M.A.; Jeon, B.H. Combined effects of sulfamethazine and sulfamethoxazole on a freshwater microalga, Scenedesmus obliquus: Toxicity, biodegradation, and metabolic fate. J. Hazard. Mater. 2019, 370, 138-146. [CrossRef]

40. Gojkovic, Z.; Lindberg, R.H.; Tysklind, M.; Funk, C. Northern green algae have the capacity to remove active pharmaceutical ingredients. Ecotoxicol. Environ. Saf. 2019, 170, 644-656. [CrossRef]

41. Talboom, S.N.; Carrillo-Nieves, D.; Rostro-Alanis, M.J.; Crus Quiroz, R.; Barceló, D.; Iqbal, H.M.N.; Parra-Saldivar, R. Algal-based removal strategies for hazardous contaminants from the environment-A review. Sci. Total Environ. 2019, 665, 358-366. [CrossRef]

42. Maryjoseph, S.; Ketheesan, B. Microalgae based wastewater treatment for the removal of emerging contaminants: A review of challenges and opportunities. Case Stud. Chem. Environ. Eng. 2020, 2, 100046. [CrossRef]

43. Villar-Navarro, E.; Baena-Nogueras, R.M.; Paniw, M.; Perales, J.A.; Lara-Martín, P.A. Removal of pharmaceuticals in urban wastewater: High rate algae pond (HRAP) based technologies as an alternative to activated sludge based processes. Water Res. 2018, 139, 19-29. [CrossRef] [PubMed]

44. Ndoun, M.C.; Elliot, H.A.; Presidendanz, H.E.; Williams, C.F.; Knopf, A.; Watson, J.E. Adsorption of pharmaceuticals from aqueous solutions using biochar derived from cotton gin waste and guayule bagasse. Biochar 2020, in press. [CrossRef]

45. Magee, E.; Zhou, W.; Yang, H.; Zhang, D. The effect of biochar application in microalgal culture on the biomass yield and cellular lipids of chlorella vulgaris. In Proceedings of the Conference: Chemeca 2013: Challenging Tomorrow, Brisbane, Australia, 29 September-2 October 2013.

46. Liao, N.; Li, Q.; Zhang, W.; Zhou, G.; Ma, L.; Min, W.; Ye, J.; Hou, Z. Effects of biochar on soil microbial community composition and activity in drip-irrigated desert soil. Eur. J. Soil Biol. 2016, 72, 27-34. [CrossRef]

47. Zhu, X.; Chen, B.; Zhu, L.; Xing, B. Effects and mechanisms of biochar-microbe interactions in soil improvement and pollution remediation: A review. Environ. Pollut. 2017, 227, 98-115. [CrossRef]

48. Khalid, A.A.H.; Yaakob, Z.; Abdullah, S.R.S.; Takriff, M.S. Analysis of the elemental composition and uptake mechanism of Chlorella sorokiniana for nutrient removal in agricultural wastewater under optimized response surface methodology (RSM) conditions. J. Clean. Prod. 2019, 210, 673-686. [CrossRef]

49. Zhang, Y.; Guo, J.; Yao, T.; Zhang, Y.; Zhou, X.; Chu, H. The influence of four pharmaceuticals on Chlorellapyrenoidosa culture. Sci. Rep. 2019, 9, 1624. [CrossRef]

50. Azevedo, F.C.R.; Vaz, I.C.D.; Barbosa, F.A.R. Toxicological effects of ciprofloxacin and chlorhexidine on growth and chlorophyll a synthesis of freshwater cyanobacteria. Braz. J. Pharm. Sci. 2019, 55, e17661. [CrossRef]

51. Kim, E.; Jung, C.; Han, J.; Her, N.; Park, C.M.; Son, A.; Yoon, Y. Adsorption of selected micropollutants on powdered activated carbon and biochar in the presence of kaolinite. Desalin. Water Treat. 2016, 57, 27601-27613. [CrossRef] 